\title{
Jeolojik Miras Niteliğindeki Doğal Taşların Peyzaj Tasarımında Kullanım Olanakları
}

\author{
Ufuk YÜKSEL ${ }^{1}$, Şehriban ERASLAN ${ }^{2 *}$ \\ ORCID 1: 0000-0001-9523-8334 \\ ORCID 2: 0000-0001-8973-1480 \\ ${ }^{1}$ Keçiborlu Belediyesi, Fen İ̧̧leri Müdürlügüu, 32700, Keçiborlu, Isparta, Türkiye. \\ ${ }^{2}$ Süleyman Demirel Üniversitesi, Mimarlık Fakültesi, Peyzaj Mimarlığı Bölümü, 32260, Isparta, Türkiye. \\ *e-mail: sehribaneraslan@sdu.edu.tr
}

\section{Öz}

Türkiye, doğal taş rezervi ve çeşitliliği bakımından zengin bir ülke olup jeolojik miras niteliğinde doğal taşların olduğu bir ülkedir. Türkiye'de jeolojik miras niteliği taşıyan doğal taşların ekonomik, dayanıklı, uzun ömürlü ve estetik olma özellikleri, peyzaj mimarlığı alanında bu taşların yoğun biçimde kullanılmasııı beraberinde getirmektedir. Akdeniz bölgesindeki jeolojik miras niteliğindeki doğal taşların tespiti ve peyzaj mimarlığında kullanım alanlarının araştırılması bu çalışmanın çıktıları olarak belirlenmiştir. Jeolojik miras niteliğindeki doğal taşların tespitine yönelik öncelikle kavramsal çerçevenin anlaşılması için literatür taramasına ihtiyaş duyulmuştur. Sonrasında bu taşların miras niteliğine vurgu yapmak ve tespitine yönelik, Akdeniz Bölgesinde antik kentlerde yerinde gözlem, mevcut durum tespiti ve fotoğraflama yapılmıştır. Akdeniz yöresindeki doğal taşların özellikleri, genellikle kullanıldıkları yerler belirlenmiş ve elde edilen bulgulara göre jeolojik miras niteliği taşıyan doğal taşların peyzaj mimarlığı meslek disiplinine yönelik uygun kullanım alanlarına ilişkin öneriler getirilmiştir.

Anahter Kelimeler: Jeolojik miras, doğal taş, peyzaj mimarlığı

\section{Usage Possibilities of Natural Stones as Geological Heritage in Landscape Design}

\begin{abstract}
Turkey which is a country with regard to natural stone reserve and diversity, has natural stones as geological heritage. In Turkey, natural stones having geological nature of inheritance have features as economic, resistant, lost lasting and aesthetic. So, these stones are intensely used in Landscape Architecture field. The detection of natural stones in geological nature of inheritance in the Mediterranean Region and investigation of the usage areas in landscape architecture has been identified as outcomes of this work. Firstly it was needed to literature for understanding the conceptual framework for the detection of natural stone in the geological nature of inheritance. After that, in the ancient cities in the Mediterranean Region in situation observation, existing situation, photographing were done to emphasize the heritage qualities of these stones. The features of natural Stones in Mediterranean Region, are determined where they usually used and according to the findings.
\end{abstract}

Atıf: Yüksel, U., Eraslan, Ş. (2019). Jeolojik Miras Niteliğindeki Doğal Taşların Peyzaj Tasarımında Kullanım Olanakları. Mimarlık Bilimleri ve Uygulamaları Dergisi (MBUD), 4 (1), 69-89.

DOI: $10.30785 / \mathrm{mbud} .468265$

*Bu makale, SDÜ Fen Bilimleri Enstitüsü Peyzaj Mimarlığı Anabilim Dalında “Jeolojik Miras Niteliğindeki Doğal Taşların Peyzaj Mimarlığında Kullanım Alanları" isimli Yüksek Lisans Tezinden üretilmiştir. 
Characteristics of natural stones in Mediterranean Region are determined according to where they are generally used. According to the findings, landscape architecture of the geological heritage of natural Stones brought suggestions for suitable usage areas for the professional discipline.

Keywords: Geological heritage, natural stone, landscape architecture

\section{Giriş}

Doğal taşlar, geçmişten bugüne insan hayatında önemli bir yere sahip olmuştur. Illk çağlarda barınak amacıyla kullanılan doğal taşlar bugün birçok alanda kullanılan bir materyal haline gelmiştir. Geçmişten bugüne jeolojik bir miras olarak gelen doğal taşlar, aynı zamanda kültürel bir değer niteliği taşımaktadır. Doğal taşların jeolojik miras olarak sürdürülebilir olması ve geleceğe taşınması ihtiyacı, böyle bir çalışma konusu seçilmesinde temel etkenlerden birisidir. Doğal taşların peyzaj tasarımı alanında kullanımının yaygın olması da bu konunun seçilmesinde etkili olmuştur.

Günümüze kadar gelen doğal taşların sürdürülebilir özgün tasarımlar da kendine yer bulması için "jeolojik miras niteliği" kavramı çerçevesinde gündeme getirilmesinin önemli olduğu düşünülmektedir. Ekolojik sistem ve doğa ile uyumlu bir nesne olan doğal taşların Akdeniz Bölgesinde tespiti, çalışmayı önemli bir noktaya taşımaktadır. Bu taşların sahip olduğu nitelikler ve fonksiyonların anlatımı çalışmanın önemini oluşturan bileşenler arasındadır. Jeolojik miras niteliğindeki doğal taşların peyzaj tasarım alanındaki kullanım alanlarının potansiyelinin belirlenmesi açısından da çalışma önem arz etmektedir.

Bu çalışmada doğal taşların peyzaj tasarım alanındaki kullanım alanları belirtilirken, jeolojik miras anlamında da önemi gözetilerek vurgulanmak istenmektedir. Akdeniz bölgesinde jeolojik miras niteliğindeki doğal taşların neler olduğu ve peyzaj mimarlığı çalışmalarında kullanılabilecek bu doğal taşların özellikleri, türleri, ocak yerleri, üretildikleri boyutlar, formlar, kullanım yer ve amaçlarının ayrıntılı bir şekilde araştırılması hedeflenmiştir.

\subsection{Jeolojik Miras Kavramı}

İlkçağlardan beri insanların yapıları, konutları ve yaşadıkları diğer yerleri doğal taşlardan yapmaya özen göstermeleri bugün doğal taş kullanımını bir kültür haline getirmiştir. Ayrıca yaşam seviyesi yükselen toplumların, dekoratif, güzel görünümlü ve dayanıklı olması nedeniyle doğal taşı tercih etmeleri bu malzemeyi refahın ve zenginliğin sembolü haline getirmiştir. Doğal taşın insan hayatına girmesi binlerce yıl öncesine dayanır. Yazılı olmayan tarih sayfalarından bugüne insan yaşamında önemli yer edinen doğal taş, ilk kez ilkel insanlar tarafından doğal yapısı değiştirilmeden günlük eşya ya da silah olarak kullanılmıştır. Tarihi, çok eskilere (Helen dönemine) rastlayan doğal taş ocakları hala işletilmektedir. Antik çağlarda da çıkartılan doğal taşların, karayolu ile Efes Antik Kentine, oradan da gemiler ile Roma'ya taşındığı, Vatikan ve Roma'da birçok yapıda kullanıldığı ve bu doğal taşların Türkiye'den gittiği kanıtlanmıştır (Değerli, 2015).

Bilimsel öneme ve belge niteliğine sahip, kaybolması durumunda bulunduğu yerin jeolojik geçmişini açıklamanın mümkün olmayacağı istif, kayaç, mineral, fosil topluluğu, yapı, doku, yer şekli vb. oluşumlara jeolojik sit (jeosit), yok olma tehdidi altında olanlara da jeolojik miras (jeomiras) adı verilmektedir. Jeosit bilimsel bir tanım ve fakat jeomiras onun toplumsal ifadesidir (Kazancı ve Gürbüz, 2014). Toplumsal bir ifade niteliği taşıyor olması, jeolojik miras kavramını önemli bir konuma taşımaktadır.

Jeolojik miras kavramı başka bir tanımda şu şekilde açıklanmaktadır: "Jeolojik miras (jeomiras), yok olması durumunda bulunduğu bölgeye ait bilgi ve jeolojik bir belgenin kaybolacağı, nadir bulunan, yok olma tehdidi altındaki jeosittir" (Kazancı vd., 2015). Yapılan tanımdan hareketle jeolojik miras kavramı gereğince nadir bulunan ve yok olma tehdidi bulunan jeositlere dikkat çekildiği değerlendirmesi yapılabilir.

Yerbilimlerinin bilgi kaynağı olan doğal taşlar, yaşamın değilse bile dünyadaki gelişmelerin ve kültürün temeli olmuştur. Bunu anlamak için, örneğin ilk insanların el baltalarını, yerleşim mağaralarını, Göbekli Tepe'yi, Mısır piramitlerini, Efes harabelerini, Ayasofya'yı, Selimiye Camii'ni, Anıtkabir'i, Kaşıkçı elmasını veya müzelerdeki antik zaman taşlarını görmek yetecektir (Çelik, 2003). 
Doğal taşların dünyadaki gelişmeler ve kültürün yansıması konumunda olması ve buna ilişkin pek çok farklı örneğin bulunması, doğal taşların araştırılacağı çalışmanın odak noktalarından birisi konumundadır.

Aşağıda Şekil 1.1 üzerinde Türkiye'nin bazı önemli jeolojik miras alanları hakkında bilgiler yer almaktadır.

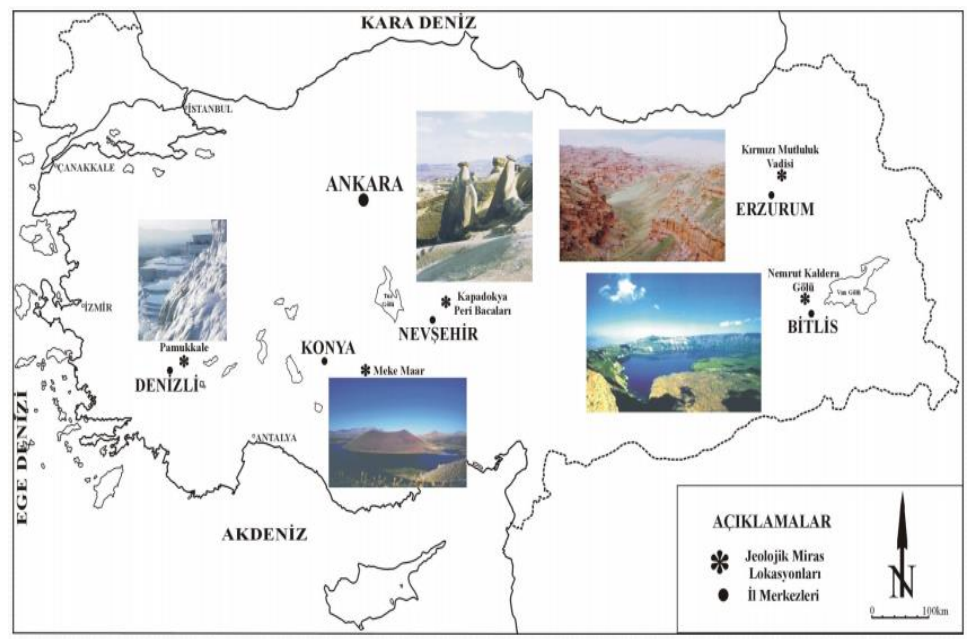

Şekil 1.1 Türkiye'nin Önemli Jeolojik Miras Alanları (URL-1)

Şekil 1.1'de görüldüğü üzere Türkiye'de Denizli, Konya, Nevşehir, Erzurum ve Bitlis, jeolojik miras açısından diğer şehirlerin önüne geçmiş durumdadır. Bu şehirlerdeki jeolojik mirasın korunması, Türkiye'nin sahip olduğu zenginliğin sürmesine katkısı sebebiyle önemlidir. Ülkenin farklı bölgelerinde jeolojik miras alanlarının bulunması, Türkiye'nin jeolojik miras açısından bulunduğu konumun önemini gösteren ayrıntılardan birisidir. Bu nedenle Türkiye'de bulunan jeolojik mirasa sahip çıkılması yönünde yürütülen girişimlerin tamamı oldukça önemli bir konuma gelmektedir.

Bu kapsamda Akdeniz yöresinde bulunan jeolojik miras niteliğindeki doğal taşların belirlenmesi de "jeolojik miras" kavramı açısından önemli katkı sağlayacaktır.

\subsection{Türkiye'de Doğal Taş Varlığı}

Doğal taşlar açısından Türkiye hem rezerv hem de çeşitlilik yönünden büyük bir potansiyele sahip görünmektedir. Sahip olduğu coğrafi konumun etkisiyle Türkiye, doğal taş varlığı ve çeşitliliği açısından öne çıkan ülkeler arasında yer almaktadır (Taşlıgil ve Şahin, 2016).

Türkiye'de jeomiras nitelikli doğal taşların varlığına ilişkin değerlendirme Şekil 1.2 üzerinde gösterildiği gibidir.

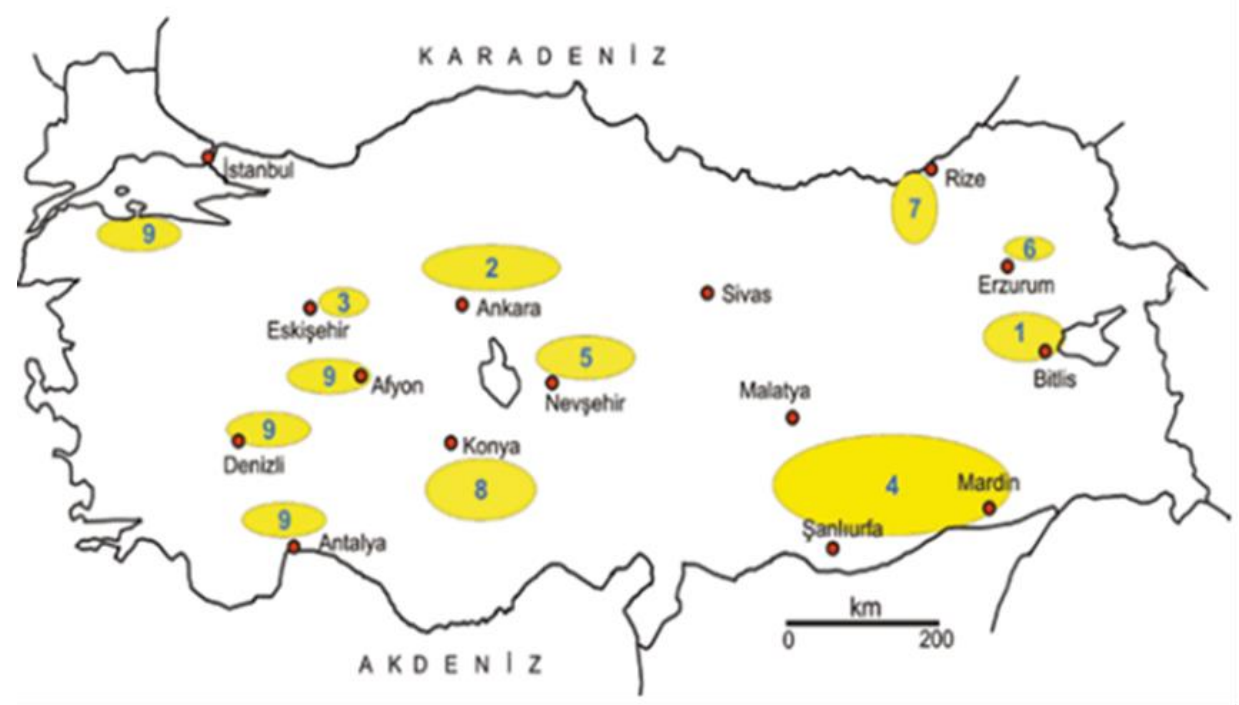


Şekil 1.2. Türkiye'de Jeomiras Nitelikli Doğal Taş Varlığı (Kazancı ve Gürbüz, 2014)

Şekil 1.2'de gösterilen taşlar açıklanacak olduğunda 1 numaralı taş Ahlat taşı, 2 numaralı taş Ankara taşı ve 3 numaralı taş lüle taşıdır. 4 numaralı bölgede Midyat taşı yer almakta iken 5 numaradaki taş Nevşehir taşı olarak bilinmektedir. 6 numarada yaygın olarak bilinen Erzurum Oltu taşı dikkat çekmektedir. 7 numaralı taş Pileki taşı, 8 numaralı taş Sille taşıdır. Farklı bölgelerde varlığı gözlenen 9 numarada ise traverten ve mermer yatakları işaret edilmektedir. Bu noktada özellikle Ege bölgesinin öne çıktığı görülmektedir. Yukarıdaki şekilde sarı renklerin büyüklüğü, doğal taşların rezerv miktarının büyüklüğüyle orantılı olarak işaretlenmiştir. Dolayısıyla Türkiye'de doğal taş varlığı konusunda Midyat taşı rezervlerinin daha yüksek düzeyde olduğu görülmektedir.

Pek çok farklı alanda kullanılıyor olması, doğal taşların açıklanmasında önemli bir yere sahiptir. Çizelge 1.1'de doğal taşların kullanım alanları ve bu alanların yoğunlukları açıklanmaktadır.

Çizelge 1.1. Doğal Taşların Kullanım Alanları ve Dağılımı (Sel, 2006)

\begin{tabular}{|c|c|}
\hline Kullanım Alanı & Kullanım Payı (Yüzde \%) \\
\hline Taban Döşeme & 36,5 \\
\hline Mezar Taşı & 17,5 \\
\hline Özel İşler & 13,0 \\
\hline Heykel & 10,0 \\
\hline İç Duvar Kaplaması & 9,50 \\
\hline Dış Duvar Kaplaması & 7,50 \\
\hline Basamak & 3,50 \\
\hline Diğer Alanlar & 2,50 \\
\hline Toplam & $\mathbf{1 0 0 , 0 0}$ \\
\hline
\end{tabular}

Ocaklardan söküm ve sökülen taşların işlenmesi için teknoloji devamlı yenilenmekte, yenilenen teknoloji ile daha çok üretim yapılmaktadır. Bu süreçte doğal taşın kullanım alanları çeşitlenmiş ve özel bir terminoloji doğmuştur. Terimlerin bazıları standartlara girmiş ise de (bkz. TSEN-12440/2008), büyük çoğunluğu salt kullanım yerini anlatmaktadır. Terimlerin bazıları şunlardır (Kazancı ve Gürbüz, 2014):

- Yapı taşları; özel bir anlam yüklenmediği sürece binaların kaba iskeletlerinde (dış ve iç duvarlar) kullanılan doğal taşları anlatır.

- Mermer; jeolojik anlamda değil de ticari anlamda kullanılan bir terimdir ve parlatılabilen bütün doğal taşlar bu adla anılmaktadır.

- Süs taşları; kişisel eşya olarak veya dekorasyon amaçlı kullanılan taşlardır.

- Kıymetli ve yarı kıymetli taşlar; süs taşlarının bir alt grubu olmakla beraber çoğunlukla mücevherat olarak değerlendirilirler.

- Kaplama taşları; ekseri binalarda iç ve dış cephe kaplamalarında kullanılan taşlardır. Çoğunlukla Kayrak taşı olarak pazarlanmaktadır.

- Yantu taşları; heykelcilikte kullanılan taşlardır.

- Dekorasyon taşları; bina iç ve dış süslemelerinde kullanııılar.

- Dekoratif taşlar; doğrudan kendisi süs eşyası olan taşlardır, ekseri vazo, sehpa, çiçeklik olarak değerlendirirler.

- Açık alan yapı taşları; şehircilikte ve peyzajlarda kullanılan doğal taşlar olup park bahçe taşları, meydan taşları, yol taşları, çeşme taşları ve heykel/anıt taşları olarak alt gruplara ayrılmaktadır.

- Tespih taşları; el işlemeciliği taşları olarak da bilinirler. 
- Isı yalıtım taşları; yalıtım amacıyla kullanılırlar.

- Fırın ve şömine taşları; Son yıllarda çoğunluğu suni yolla üretilmekte olup bununla beraber doğal olanları da vardır.

- Inşaat sektörü doğal taşları; başlıca beyaz mermer, renkli mermer, sert taşlar, traverten olarak dört grupta toplanır.

- Ticari doğal taşlar; ocaklardan sökülüp satılan ve ürün devamlılığı olan taşlardır.

- Parlatılabilen doğal taşlar; doğrudan mermerleri ifade eden bir tanımdır. Kesme taşlar; inşaata uygun boyutlarda hazırlanmış, ekseri kübik taşlardır. Yol döşemesi veya duvar yapımında kullanılır.

- Kamu ve özel yapılarda doğal taşlar; kamu veya özel kurumlar tarafından inşa edilen, temsil özelliği olan ve/veya saygınlık için dikilen yapılarda kullanılan, kullanımı mimarı tarafından bizzat tarif edilen taşlardır. İç mekân ve dış mekân taşları olarak ayrııılar.

\subsection{Peyzaj Tasarımında Sıklıkla Kullanılan Doğal Taşlar}

Doğal taşların peyzaj alanındaki kullanımı ocaktan çıktığı biçimde doğal olarak olabildiği gibi işlenerek kesme taş biçiminde de gerçekleşebilir. Çakıllar ve kayrak taşı, işlenmeksizin kullanılan taşlar olarak öne çıkmaktadırlar. Peyzaj tasarımında kullanılan doğal taşlar; granit, bazalt, andezit, kumtaşı, traverten, kayrak, kireç taşı, mermer ve çakıl taşı şeklinde sıralanmaktadır (Altınçekiç, 2001).

Zarafeti, dayanımı ve potansiyel zenginliği ile asırlardan beri insanoğlunun vazgeçilmez sanat kollarından birini ve yapı elemanlarını oluşturan doğal taşı Hititler, eski Mısırlılar, Frigyalılar, Mezopotamya Medeniyeti, Persler, Lidyalılar, Eski Yunanlılar, Romalılar, Selçuklular, Osmanlılar ve diğer birçok medeniyet günümüze kadar gelen ve çağlarına ışı tutan heykellerinde ve yapılarında kullanmışlardır (Ulu, 2009)

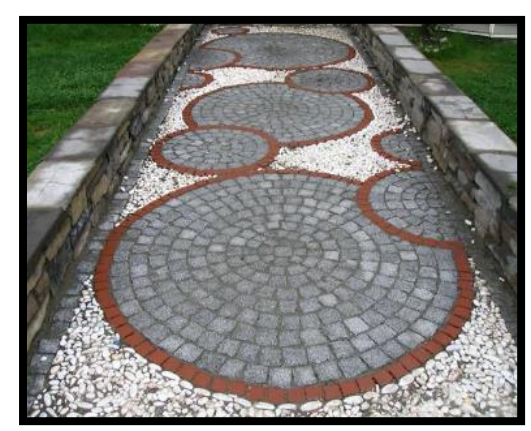

Peyzaj tasarımında doğal taşların kullanımı açıklanırken taşların kullanımına örnek olarak fotoğraflara yer verilmiştir. Şekil 1.3'te Granit küp taşının geometrik şekilli tasarımlarla yürüyüş yollarında kullanımı görülmektedir.

Şekil 1.3. Granit Taşının Peyzaj Tasarımında Kullanımı (URL-2)

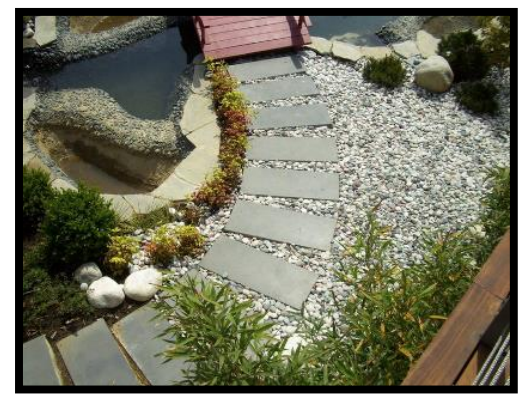

Bazalt taşı peyzaj tasarımlarında sağlam yapısı ve uzun ömürlü olması nedeniyle yürüyüş yolları ve duvar kaplamalarında sıklıkla tercih edilmektedir. Şekil 1.4'de bazalt taşının adım taşı şeklinde kullanımı görülmektedir.

Şekil 1.4. Bazalt Taşının Peyzaj Tasarımında Kullanımı (URL-3) 


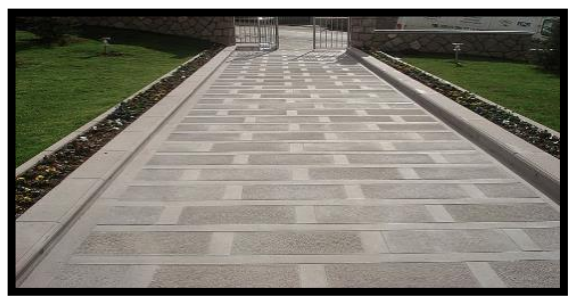

Andezit taşın peyzaj tasarımlarında bahçe bordürü, yağmur suyu oluğu ve farklı yüzey işlemleri (kumlama) uygulanarak zemin döşeme malzemesi olarak kullanılmaktadır. Şekil 1.5 'te bu uygulamaların hepsi görülmektedir.

Şekil 1.5. Andezit Taşının Peyzaj Tasarımında Kullanımı (URL-4)

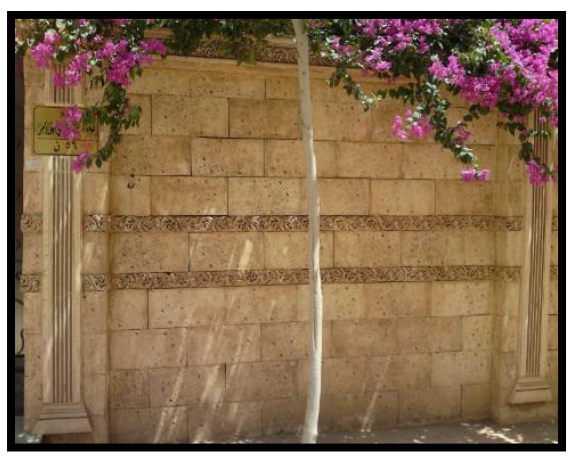

Kumtaşı işlenebilir yapısı ile peyzaj tasarımlarına renk getirmekte ve kolay çözüm olanakları sunmaktadır. Kumtaşından yapılan söve ve küpeşte örneği Şekil 1.6' da görülmektedir.

Şekil 1.6. Kumtaşının Peyzaj Tasarımında Kullanımı (URL-5)

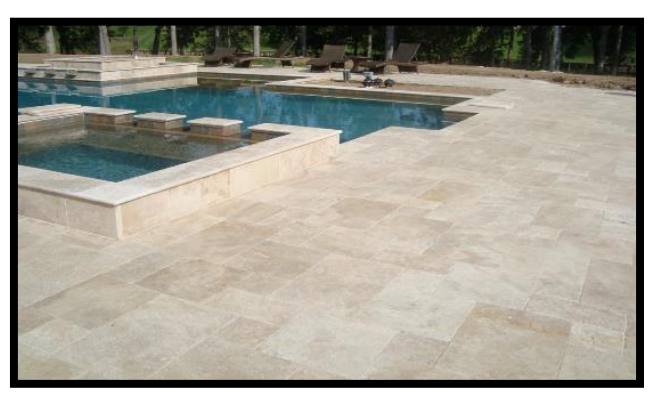

Traverten rengi, doğal görüntüsü ve kaymaz yüzeyi ile peyzaj tasarımlarda duvar kaplamalarında, havuz kenarlarında ve merdiven tasarımlarında sıkça kullanılmaktadır. Şekil 1.7' de havuz kenarı kullanım şekli görülmektedir.

Şekil 1.7. Traverten Taşının Peyzaj Tasarımında Kullanımı (URL-6)

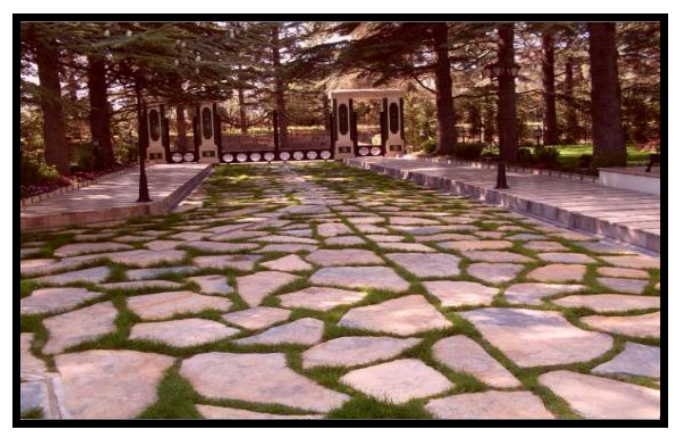

Kayrak taşı peyzaj tasarımlarına pratik çözümler sunmaktadır. Şekil 1.8'de çim derzli kayrak taşı uygulaması görülmektedir.

Şekil 1.8. Kayrak Taşının Peyzaj Tasarımında Kullanımı (URL-7) 


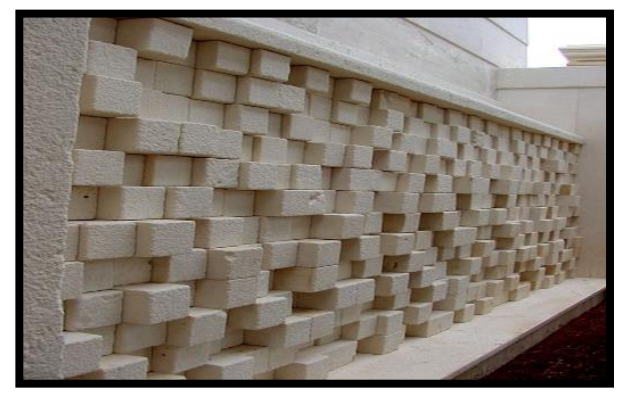

Peyzaj tasarımlarında kireç taşının mermerleşmiş hali olan limra taşı kullanılmaktadır. Açık renkli ve yumuşak yapıda olması nedeniyle zemin döşemelerinde pek fazla tercih edilmemektedir. Şekil $1.9^{\prime}$ da üç boyutlu duvar kaplaması örneği görülmektedir.

Şekil1.9. Kireç Taşının Peyzaj Tasarımında Kullanımı (URL-8)

Çeşitli kalınlıklarda plakalar halinde üretilen ve tarihi mekânlar içinde uygun bir doğal taş olan mermerler (Uzun, 1998), dış mekân uygulamalarında, çoğunlukla 25-30 mm. kalınlığında 300 mm'den 900 mm'ye kadar uzunluktaki ve genişlikteki mermer plakalar halinde kullanılır (Seçkin, 1997).

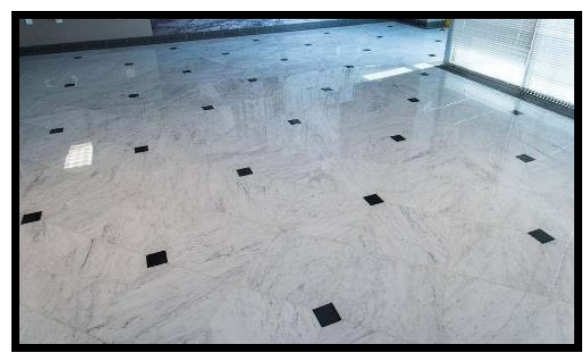

Mermer iç ve dış mekânların vazgeçilmez bir yapı malzemesidir. Renk skalası oldukça fazladır yüzeyi değişik işlemlerden istenilen parlaklığa kolayca gelebilir. Peyzaj tasarımlarda sert zemin döşemesi, merdiven basamakları, heykel, çeşme gibi birçok uygulama alanı vardır. Şekil 1.10 'da mermerin sert zemin döşemesi görülmektedir.

Şekil 1.10. Mermer Taşının Peyzaj Tasarımında Kullanımı (URL-9)

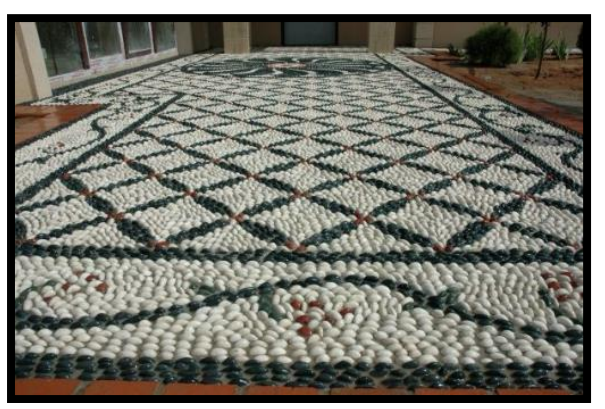

Çakıl taşlarının peyzaj kullanımı bina girişlerinde vurgu yapabilmek için diğer zeminlerden farklı olarak uygulanmakta çok rahat bir şekilde renk çeşitleriyle farklı motifler uygulanabilmektedir. Şekil 1.11'de çakıl taşları ile oluşturulmuş bitki ve geometrik desenler tasarımı görülmektedir.

Şekil 1.11. Çakıl Taşının Peyzaj Tasarımında Kullanımı (URL-10)

Tasarım ilkeleri, doğal taşların peyzaj tasarımında kullanımı konusunda dikkate alınması gerekir. Bunlar; birlik, oran, ölçek, denge, simetri, ritim, zıtlık ilkeleri şeklinde sıralanmaktadır (Yavuz, 2010).

Doğal taşların peyzaj tasarımında kullanımına ilişkin görsellerde görüldüğü üzere peyzaj tasarımında doğal taşların geniş bir kullanım alanı bulunmaktadır. Taşların sahip oldukları niteliklere göre doğal taşların peyzaj tasarımındaki kullanımının şekillendiği görülmektedir. Doğal taşların kullanım alanlarının geniş olması, peyzaj tasarımında doğal taşların kullanım biçimi ve kullanım sıklığına yansımış durumdadır.

\section{Materyal ve Yöntem}

Materyal ve yöntem bölümünde jeolojik miras niteliğindeki doğal taşların peyzaj mimarlığında kullanım alanlarının araştırıma biçimine dair bilgi verilmektedir. Yapılan araştırma gereğince izlenen yönteme ve faydalanılan materyallere ilişkin açıklamanın, ulaşılacak olan sonuçların - jeolojik miras bakış açısıyla - daha sağııkı bir biçimde anlaşılmasına katkıda bulunması hedeflenmektedir.

\subsection{Materyal}

Literatür araştırması yanında Akdeniz bölgesinde jeolojik miras niteliği taşıyan doğal taşların tespit edilmesine yönelik olarak materyal kapsamında Antalya Aspendos, Burdur Sagalassos, Isparta Pisidia, 
Mersin Olba, Hatay İssos, Kahramanmaraş Germanicia antik kentleri ve Adana Taşköprü değerlendirilmeye alınmıştır.

Çalışma alanlarının Akdeniz Bölgesi'ndeki yerlerine ilişkin harita Şekil 2.1'de görülmektedir.

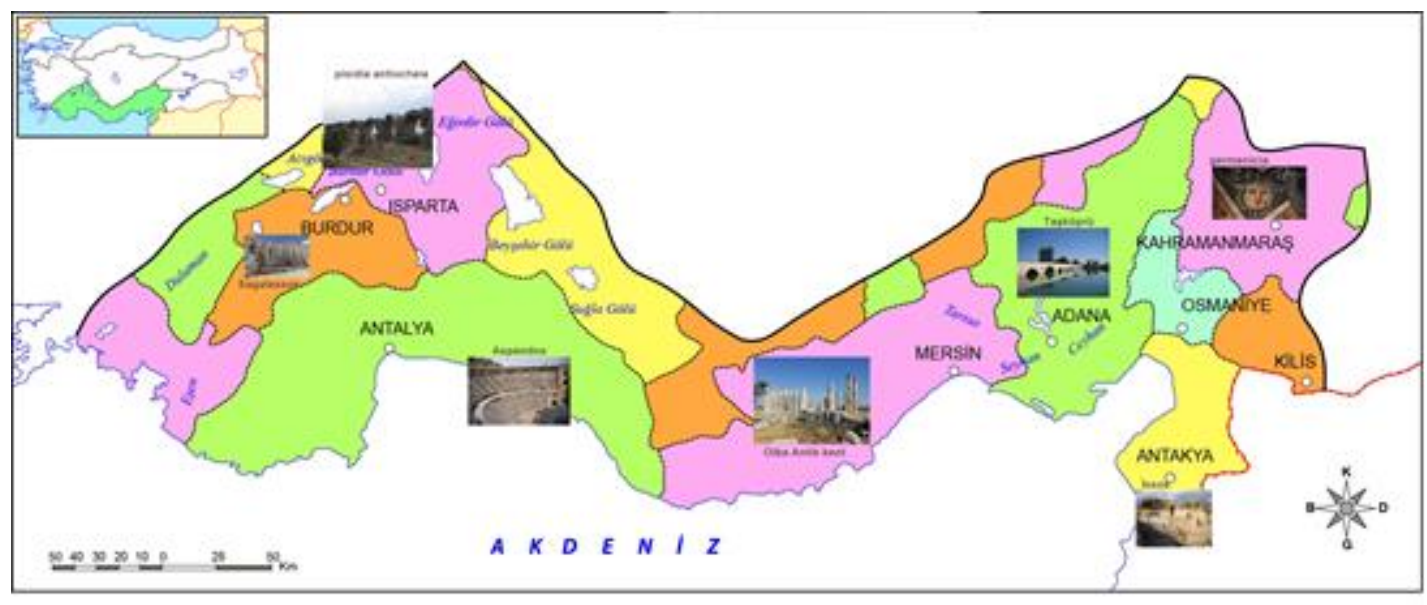

Şekil 2.1. Akdeniz Bölgesi Antik Kent Haritası

\subsection{Yöntem}

Jeolojik miras niteliğindeki doğal taşların tespiti için öncelikle bu taşların miras niteliğine vurgu yapmak ve tespitine yönelik olarak yapılan incelemeler sonucunda; Akdeniz Bölgesinde bulunan her ilden birer antik kent seçilmiş ve yerinde gözlem, mevcut durum tespiti ve fotoğraflama yapılmıştır. Antik kentlerin seçiminde dikkat edilen konular kentlerin günümüze kadar ayakta kalabilmiş olması, restorasyon çalışmalarında kullanılan taşların yöre civarından çıkarılan orijinaline en yakın doğal taşlardan seçilmesi ve Akdeniz Bölgesi'nin en iyi korunan antik kentleri olmasıdır.

Antik kentlerde kullanılan doğal taşların yanında kişisel bilgi ve gözlem ile de jeolojik miras kapsamında yer aldığı belirlenen doğal taşların bölgelerdeki varlığına ve kullanımına yönelik araştırma süreci de araştırmanın yöntemi kapsamında kendisine yer edinmiştir. Doğal taşların jeolojik miras yönüyle ele alınması konusunda konuyla ilgili güncel kaynaklardan faydalanılmıştır.

Çalışma içerisinde Akdeniz yöresinde jeolojik miras niteliğindeki doğal taşların neler olduğu ve peyzaj mimarlığı çalışmalarında kullanılabilecek bu doğal taşların özellikleri, türleri, ocak yerleri, üretildikleri boyutlar, formlar, kullanım yer ve amaçlarının ayrıntılı bir şekilde araştırılmıştır.

\section{Araştırma Bulguları ve Tartışma}

Araştırma bulguları ve tartışma kısmında öncelikli olarak jeolojik miras niteliği taşıyan doğal taşların tespiti, araştırıının kişisel bilgi ve gözlemleri yardımıyla, sonrasında seçilen antik kentler özelinde ulaşılan verilerin mevcut değerlendirilmesi ile birlikte araştırmanın bulgularının tamamlanması öngörülmüştür.

\subsection{Akdeniz Bölgesindeki Antik Kentler}

Dünya üzerinde kentleşmenin geçmişi yaklaşık olarak on bin yıl öncesine uzanmaktadır. Dünyanın farklı bölgelerinde geçmişi farklı dönemlere uzanan antik kentler bulunmaktadır. Mezopotamya'daki antik kentlerin yaklaşık altı bin yıl öncesine uzandığı ifade edilmektedir (Karaca, 2017). Çalışmanın bu kısmında Akdeniz bölgesindeki her ilden bir antik kent seçilmiştir. Antik kentlerin seçiminde dikkat edilen konular kentlerin günümüze kadar ayakta kalabilmiş olması, restorasyon çalışmalarında kullanılan taşların yöre civarından çıkarılan orijinaline en yakın doğal taşlardan seçilmesi ve Akdeniz Bölgesi'nin en iyi korunan antik kentleri olmasıdır.

Antalya Aspendos Antik Kenti, Burdur Sagalassos Antik Kenti, Isparta Pisidia Antiokheia Antik kenti, Mersin Olba Antik Kenti, Hatay İssos (Epiphaneia) Antik Kenti, Kahramanmaraş Germenicia Antik Kenti ve tarihi eskilere dayandığı gerekçesiyle Adana Taşköprü jeolojik miras niteliğindeki doğal taşların tespiti için araştırılmıştır. 


\section{- Aspendos Antik Kenti}

Antalya Aspendos Antik Kenti, antik döneme göre Pamphylia bölgesinde kurulmuş olup günümüzde Antalya ilinin Serik ilçesine bağlı olarak Belkıs beldesinde yer almaktadır. Aspendos antik kenti Köprüçay ırmağının kenarında kurulmuştur. Antik kent, kayalık tepenin yanı sıra etrafındaki düzlükleri içermektedir (Kıraç ve Kıraç, 2011). Aspendos antik kenti, Türkiye'de en çok ilgi gören ve en çok ziyaret edilen yerlerden birisi konumundadır.

Tarihi ve kültürel bir değeri olan Aspendos antik kenti, sahip çıkılması gereken jeolojik miraslardan birisidir.

Aspendos antik kenti amfi tiyatrosunun yapımında kullanılan taşlar incelendiğinde basamaklarının dokimeion mermerinden, sütunlarının ve kemerlerinin ise günümüzde de yöre çıkarılan kireç taşından yapıldığı görülmüştür.

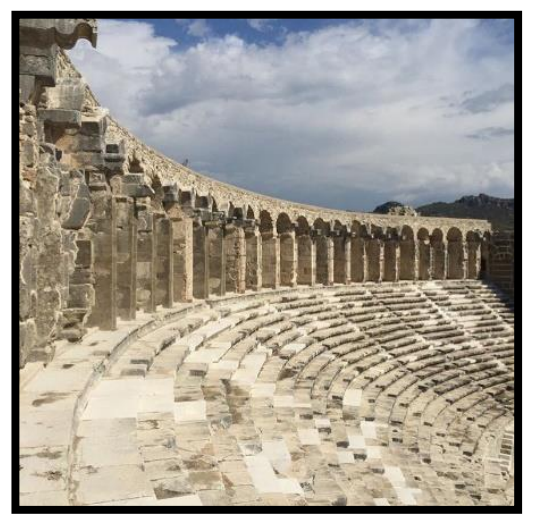

Şekil 3.1'de Aspendos antik kentinde bulunan mimari yapısı ve jeolojik miras niteliğindeki doğal taş kullanımı ile dikkat çeken Amfi Tiyatrodan bir görünüm verilmiştir.

Şekil 3.1. Aspendos Antik Kenti Amfi Tiyatro, Antalya (Yüksel, 2018)

\section{- Sagalassos Antik Kenti}

Türkiye'nin en iyi korunan antik kentlerinden birisi olan Sagalassos, Ağlasun'un - Burdur ilinin bir ilçesidir - yaklaşık olarak 7 kilometre kuzeyinde yer almaktadır. Sagalassos antik kentinde restore edilmiş bir çeşmenin yanı sıra yüksek onursal sütunlar, iki kemerli kapı, yapı kalıntıları bulunmaktadır. Sagalassos antik kentinin içinde büyük bir Roma hamamı, kütüphane, günümüzde hala akan bir çeşme, dokuz bin kişi kapasiteye sahip bir tiyatro gibi eserler yer almaktadır (URL-11).

Sagalassos antik kentini tanıtan bu bilgiler aynı zamanda jeomiras açısından açıklayıcı bir yapıya sahiptir. "Sagalossos antik kenti; Burdur’a bağlı Ağlasun ilçesindeki Sagalassos antik kenti, Unesco Dünya Miras Aday listesinde olup, geçmişi 12.000 yıl öncesine dayanmaktadır. Bu antik kent; orijinal yapısının neredeyse büyük bir kısmını korumuş durumdadır. Ağlasun'a 7 kilometre uzaklıkta bulunan kent; güvenlik ve su kaynaklarının bol olması nedeniyle, 1450 ve 1600 metre yüksekliğe kurulmuştur. 1706 da Fransız gezgin Paul Lucas tarafından bulunan kentte kazı çalışmaları, Prof. Dr. Marc Waelkens başkanlığında 1989 yılında başlamıştır. Halen de devam etmektedir" (URL-12).

Burdur Sagalassos antik kentiyle ilgili olarak şu hususların bilinmesinde fayda vardır: "bölgemizin önemli antik kentlerinden olan Sagalassos antik kentinden 1989 yılından beri devam etmekte olan arkeolojik kazılar sonucu ortaya çıkarılmış olan kültür varlıklarından Kuzey Batı Heroon yapısını süsleyen dans eden kızlar frizleri karşılamaktadır. Müze girişine göre sağ taraftaki salonda Kibyra ve Kremna antik kentlerinden gelen kireçtaşı ve mermer ağırlıklı eserler sergilenmektedir" (Burdur Arkeoloji Müzesi). Antik kentte hamam, tiyatro, çeşme, tapınak, anıtlar gibi alanlar mevcuttur. Hamamların duvarlarında 40 ton mermer kullanıldığı bilinmektedir (URL-13). 


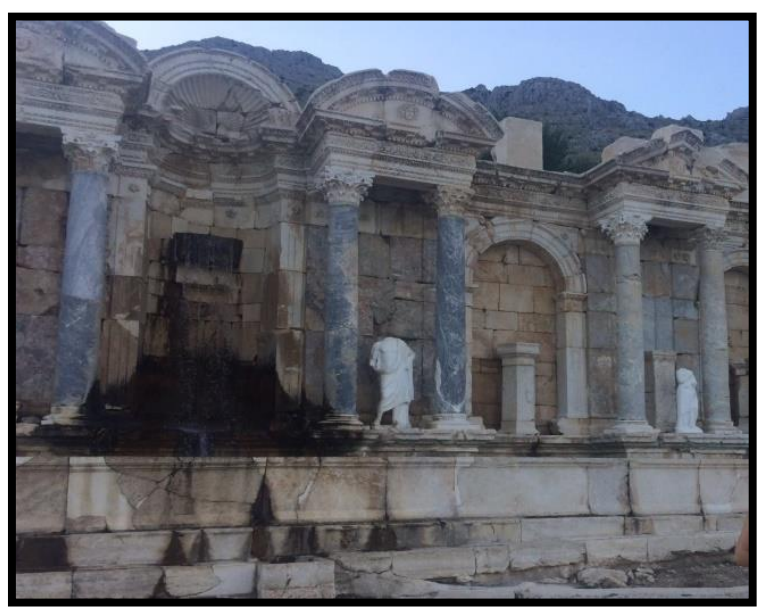

Şekil 3.2'de Sagalassos antik kentinde bulunan mimari yapısı ve jeolojik miras niteliğindeki doğal taş kullanımı ile dikkat çeken Antoninler Çeşmesinden bir görünüm verilmiştir. Çeşmenin yapımında kullanılan mermer sütunların dokimeion mermerinden yapıldığı görülmektedir. Diğer yapılarında günümüzde de yöre civarından çıkarılmaya devam eden kireç taşından yapıldığı görülmüştür.

Şekil 3.2. Sagalassos Antik Kenti Antoninler Çeşmesi, Burdur (Yüksel, 2018)

\section{- Pisidia Antiokheia Antik Kenti}

Pisidia Antiokheia Antik Kenti Isparta iline bağlı Yalvaç ilçesinin 1 kilometre kuzeyinde yer almaktadır. Pisidia Antiokheia antik kenti verimli bir arazi üzerinde yer alması sebebiyle farklı dönemlerde önemini korumuş ve farklı kültürlere ev sahipliği yapmıştır (Üstol vd., 2013). Farklı kültürlerin yaşadığı bir bölge içerisinde olması sebebiyle Isparta Pisidia Antiokheia antik kentinin jeomiras açısından zengin bir konumda olduğu söylenebilir.

Isparta Pisidia Antiokheia antik kentinin diğer özellikleri aşă̆ıdaki gibi sıralanmaktadır (Kuter ve Erdoğan, 2006):

1. Pisidia Antiokheia antik kenti Hristiyanlık dininin ikinci hac merkezlerinden birisi olarak görülmesi sebebiyle inanç turizminde önemli bir yere sahiptir.

2. Tarih, sanat gibi konularda Pisidia Antiokheia antik kenti önemli kaynaklardan birisi konumundadır.

3. Pisidia Antiokheia antik kenti, sosyal ve ekonomik açıdan belge ve kaynak niteliği taşımaktadır.

4. Yapılan kazı çalışmalarında batıya ait çok sayıda kalıntı ortaya çıkarıımıştır ve bu da antik kentin zenginliğini meydana getirmektedir.

5. Pisidia Antiokheia antik kenti konumu, tarihi geçmişi ve mimari yapısıyla özgün bir yapıdadır ve bu durum kente jeomiras çeşitliliği getirmektedir.

Yukarıda sıralanan niteliklerin her birisi Isparta Pisidia Antiokheia antik kentinin tarihi ve kültürel geçmişini ortaya koymasının ötesinde jeolojik miras yönünden konumunu açıklamada yardımcı rol üstlenmektedir.

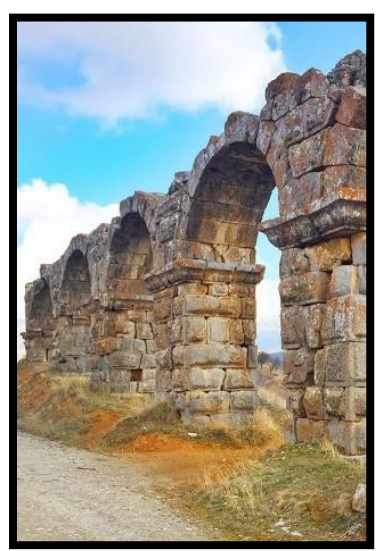

Şekil 3.3'de Pisidia Antiokheia antik kentinde bulunan mimari yapısı ve jeolojik miras niteliğindeki doğal taş kullanımı ile dikkat çeken su kemerlerinden bir görünüm verilmiştir. Yapıların diğer kısımlarında yöre civarında çıkarılan köfke taşına rastlanmış fakat kimi yapıların yıkılmış olması nedeniyle hangi yapılarda kullanıldığı belirlenememiştir.

Şekil 3.3. Pisidia Antiokheia Antik Kenti Su Kemerleri, Isparta (Yüksel, 2018) 
Isparta Pisidia Antiokheia antik kentinin yapı malzemesi olarak tuğla kullanılmıştır. Duvarlarda, örgütlerde, yer kaplamalarında tuğlaların varlığı gözlenmektedir. Tuğlalar Bizans döneminde kullanılan tuğlalara göre daha küçük olup Osmanlı İmparatorluğunun kullandığı tuğlanın boyutlarına yakın bir değere sahiptir. Isparta Pisidia Antiokheia antik kentindeki tuğlaların çoğunlukla $29 \times 29 \times 5$ cm boyutlarında olduğu görülmektedir (Kılınçarslan vd, 2007).

\section{- Adana Taşköprü}

Taşköprü, Adana kentinin en önemli simgelerinden birisi olup iki bin yıla yakın geçmişe dayanmaktadır. Uzun yıllar boyunca Asya ile Avrupa arasında önemli bir bağlayıcı vazifesi gören Taşköprü’nün farklı dönemlerde bazı restore çalışmalarının yapıldığı bir eser olarak bilinmektedir (URL, 14). Köprünün ilk yapıldığı yıllardaki özelliklerinin hala korunduğu ifade edilmektedir. Bu da Taşköprü için jeolojik miras niteliği taşıdığı değerlendirmesini mümkün kılmaktadır.

Roma döneminde yapılan Taşköprü’nün sahip olduğu nitelikler şu şekilde açıklanmaktadır: "Tarihin bütün dönemlerinde önemli bir geçiş yerinde bulunan Taşköprü, muazzam bir köprüdür. Yararlılık, sağlamlık ve estetiğin birleştiği bir mühendislik eseridir denebilir. İnşa edildiği malzeme bölge için o kadar önemlidir ki, adını inşasında kullanılan malzemeden alır. Yakın çevrede taş ve taşçı ustası bulunmadığına göre, taş bir köprü yapmak için gereken bilgi ve teknik birikimin, başka yerlerdeki köprü uygulamaları ile sağlandığı açıktır. Hem malzemenin, hem de iş gücünün uzaktan getirilmesi, inşaat ekonomisine azami dikkat edilmesini şart kılmıştır. Bu yapıt, Roma'nın organizasyon yeteneğini, teknolojiyi kullanma becerisini, bilgiyi akışkan olarak kullanabilme yeteneğini ve en önemlisi mühendislik dehasını ortaya koyar" (Ramazanoğlu, 2009).

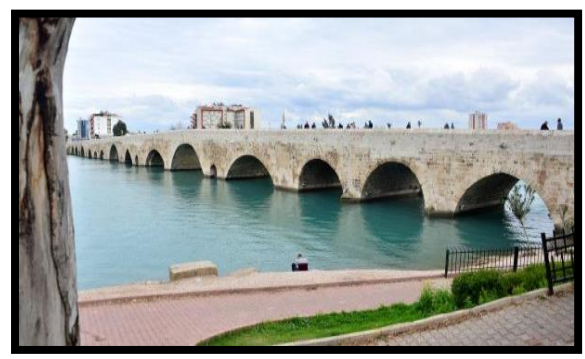

Şekil 3.4'te Adana ilinde bulunan mimari yapısı ve jeolojik miras niteliğindeki doğal taş kullanımı ile dikkat çeken Taşköprü'den bir görünüm verilmiştir. Köprünün yöre civarında çıkarılan tüf taşından yapıldığı bilinmektedir.

Şekil 3.4. Adana Taşköprü

\section{- Olba Antik Kenti}

Antik kent olarak zengin bir konumda olan Mersin'de Olba antik kenti, Soli Pompeiopolis antik kenti, Uzuncaburç antik kenti, Anemurium antik kenti, Kelenderis antik kenti gibi antik kentler bulunmaktadır. Antik dönemlerden beri Kilikya bölgesinin temel yerleşim birimlerinden olan Mersin'de yirmiden fazla antik kentin bulunduğu bilinmektedir (URL-15). Bu da kentin jeolojik miras açısından önemini meydana getirmektedir.

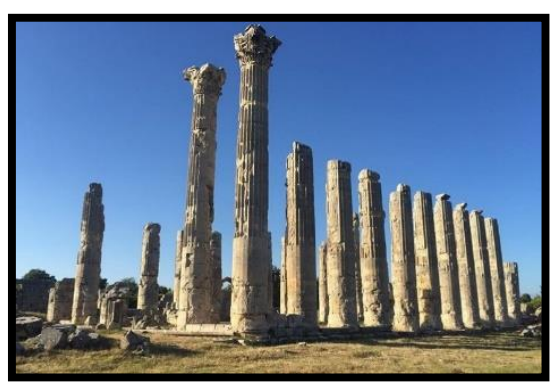

Şekil 3.5'te Olba antik kentinde bulunan mimari yapısı ve jeolojik miras niteliğindeki doğal taş işlemeciliği ile yapılan sütunlarla oluşturulan zeus tapınağından bir görünüm verilmiştir. Tapınakta bulunan sütunların yöre civarından çıkarılan tüf taşından yapıldığı bilinmektedir.

Şekil 3.5. Olba Antik Kenti Zeus Tapınağı

Mersin'in Silifke ilçesine bağı Örenköy'de yer alan Olba antik kenti, Olba Krallığının merkezi olarak bilinmektedir. Önemli bir ticaret merkezi olarak anılan bu antik kent, aynı zamanda dini açıdan önemli bir yere sahiptir. Olba antik kentindeki yapılar arasından öne çıkanları ise Roma İmparatorluğu 
dönemine aittir. Su kemeri, anıtsal çeşme, tiyatro, nekropol alanı, manastır ve katedral bu antik kentteki başlıca yapılar olarak görünmektedir (URL-16).

\section{- İssos (Epiphaneia) Antik Kenti}

"Hatay ilinin, Erzin İlçesi, Gözeneler mevkiinde yer alan İssos (Epiphaneia) Antik Kenti'nin kuruluş tarihi tam olarak bilinmemektedir. Hierokles'e göre İssos, M.Ö. 5. ve 6. yüzyılda Kilikya'nın şehirlerinden biriydi. Bölge, M.Ö. 540 yılında Perslerin hâkimiyetine girmiştir ve M.Ö. 333 yılında Büyük İskender'in Pers Kralı III. Darius'u yenmesinden sonra ise bölgede Helenistik Dönem başlamıştır. Arapça kaynaklarda şehir, genellikle siyah taştan (bazalt) yapılı binalarıyla "Kanisat assauda" olarak geçmektedir" (URL-17).

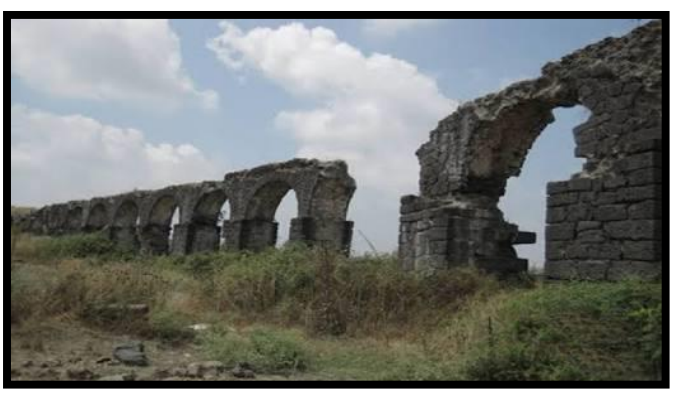

Şekil 3.6'da Bazalt yapılı su kemerleri görünümü, bu çalışma konusu ile i̇ssos antik kent ilişkisini meydana getiren hususların başında gelmektedir.

Şekil 3.6. İssos Antik Kenti Su Kemerleri (URL-18)

\section{- Germenicia Antik Kenti}

Milattan sonra 300-400 yıllarına ait olduğu belirtilen Kahramanmaraş'taki Germenicia antik kenti, Kahramanmaraş'ın arka mahallelerinde roma dönemindeki zenginlerin yaşadığı bir bölgeyi işaret etmektedir. Bölgedeki taban döşemeleri, dikkat çeken noktalardan birisidir. Kentteki mozaiklerde dönemin siyasal, sosyal, ekonomik hayatına ilişkin mozaikler görülmektedir. Kahramanmaraş'taki Germenicia antik kenti 2007 yılında yapılan bir kaçak kazı ihbarı neticesinde ortaya çıkmıştır. Germenicia antik kentinin taban mozaikleri ilgili olarak yürütülen çalışmalar devam etmektedir (URL19).

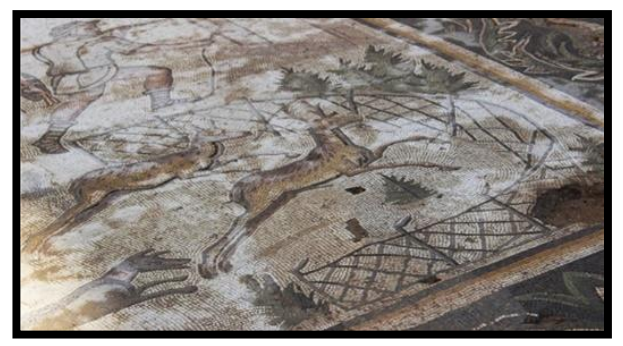

Şekil 3.7'de Germenicia antik kentinde jeolojik miras niteliğindeki doğal taşlardan yapılan taban mozaiği örneklerinden biri görülmektedir. Mozaiklerin yapımında İskenderun siyah mermeri ile birlikte farklı renklerdeki mermerlerin kullanıldığı görülmüştür.

Şekil 3.7. Germenicia Antik Kenti Taban Mozaiği (URL-20)

Hatay ve Kahramanmaraş antik kentleri hakkında verilen bilgiler göz önüne alındığında inanç turizmi potansiyelinin ön plana çıktığı değerlendirmesi yapılabilir. Özellikle Hatay'ın tarihi Paleolitik döneme kadar uzanmaktadır ve kentte farklı uygarlıklara ait antik kentlerin varlığı söz konusudur (Bingöl, 2004). Kahramanmaraş ise antik kent bakımından Hatay ilinin biraz daha gerisinde yer edinmiş durumdadır.

Türkiye'deki antik kentler hakkında verilen bilgiler, Akdeniz bölgesinin hem kültürel hem jeolojik miras anlamında ön plana çıktığını göstermesi bakımından önemlidir. Tarihin farklı dönemlerinde farklı uygarlıklara ev sahipliği yapan bu antik kentlerin her birisi sahip oldukları özgün niteliklerle birlikte jeolojik miras niteliği taşımaktadır. Bu nedenle bu antik kentlerin tarihi ve kültürel dokusunun korunması, antik kentlere sahip çıkılması, öncelikli bir görev olarak ta benimsenmelidir.

Çalışmanın bu kısmında jeomiras niteliği taşıyan doğal taşlar için kişisel bilgi, deneyim, gözlemler ve antik kentlerde yerinde gözlem sonucunda Mermer, Traverten, Kireç Taşı (Limra), Toprakkale Bazaltı, Köfke Taşı, Tüf, Geyran Taşı (Andezit) Akdeniz yöresindeki jeolojik miras niteliğindeki doğal taşlar olarak seçilmiştir. 


\subsection{Akdeniz Bölgesindeki Jeolojik Miras Niteliğindeki Taşlar}

\section{Dokimeion Mermeri}

Mermer hakkında yapılacak incelemede antik dönemlerden günümüze kadar halen bölge içerisinde ocakları bulanan ve çıkarılmaya devam eden İskenderun Siyah mermeri ile İscehisar mermeri ele alınmıştır. Afyonkarahisar'a bağıı İscehisar'da değişik renk özellikleri sunan mermerlerin varlığı söz konusudur. İscehisar'da 30'a yakın mermer ocak işletmesi ile 400 civarında mermer fabrikası bulunmaktadır. İscehisar'daki mermerlerin $0 \mathrm{~mm}$ ile $1,2 \mathrm{~mm} ; 1,2 \mathrm{~mm}$ ile $3 \mathrm{~mm} ; 3 \mathrm{~mm}$ ile $5 \mathrm{~mm} ; 5 \mathrm{~mm}$ ile $9 \mathrm{~mm}$ ve 9 ile $15 \mathrm{~mm}$ arasında değişen tane boyutları vardır. Ayrıca İscehisar mermeri beton üretimi, asfalt sektörü, dolgu hammaddesi gibi alanlarda kullanılan agrega olarak değerlendirilmektedir (Bağcı vd., 2014).

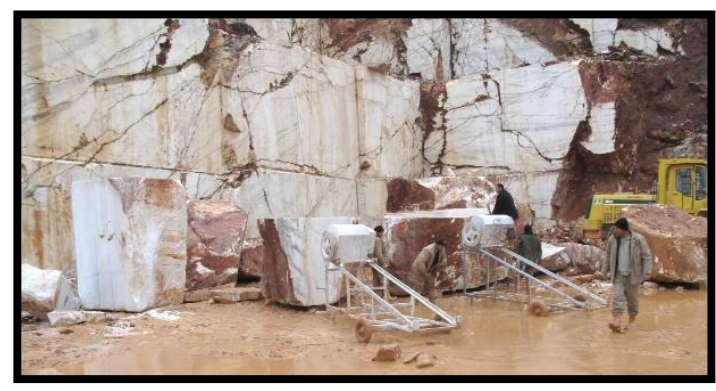

Sagalassos Antik kenti hamamlarında da kullanılmış olan İscehisar (dokimeion) Mermeri geçmişteki önemini günümüzde de korumaktadır ve Şekil 3.8'de isscehisar bölgesinde bulunan bir mermer ocağı işletmesi görülmektedir.

Şekil 3.8. İscehisar (Dokimeion) Mermeri Açık Ocak İşletmesi, Afyon (Yüksel, 2010)

\section{Traverten}

"Travertenler; jeolojik, jeomorfolojik, hidrografik, klimatolojik ve biyolojik etkinliklerin bir sonucu ortaya çıkan karbonatlı tortul bir kayaçtır. Travertenlerin esası $\mathrm{CaCO}_{3}$ olup, $\mathrm{Ca}^{+2}$ ve $\mathrm{HCO}^{-}$ce zengin yeraltı sularının genellikle bir faydan, çatlaktan ya da yarıktan yeryüzüne çıktıkları yerde fizikokimyasal, biyokimyasal olarak bünyelerindeki $\mathrm{CaCO}_{3}^{\prime}$ । çökeltmesiyle oluşur" (Polat, 2011).

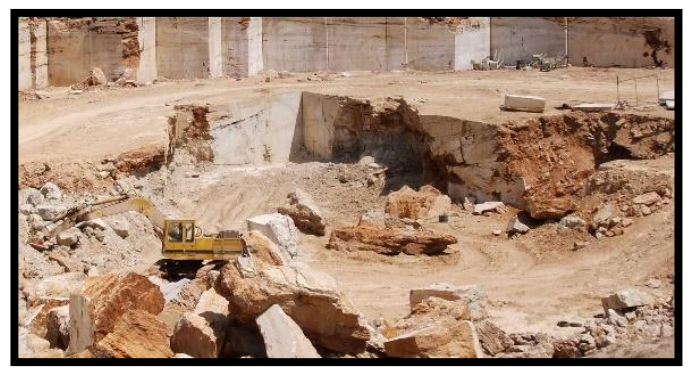

Travertenler teras tipi traverten, sırt tipi traverten, fay önü travertenleri, kendiliğinden oluşan kanal travertenleri, aşınmış örtü travertenleri şeklinde sınıflandırılmaktadır (Altunel, 1996). Şekil 3.9'da Traverten oluşumunun örneği ve açık ocak işletmesi görülmektedir.

Şekil 3.9. Traverten Açık Ocak İşletmesi, Denizli (Yüksel, 2010)

\section{Kireç Taşı (Limra)}

Antik çağlardan beri kullanılan kirecin üretilmesindeki hammadde kireç taşıdır. Kireç taşı, yüksek kalsiyumlu kireç taşları ve dolomitik kireç taşları biçiminde ikiye ayrılmaktadır. Tarım, endüstri ve diğer sektörlerde kireç kullanımının günümüzde artması ile birlikte kireç taşının önemi de benzer şekilde artış göstermektedir (Kılıç ve Anıl, 2006).

Türkiye'de farklı jeolojik yaşlarda ve yaygın biçimde bulunan kireç taşı, mermer olarak işletebilir bir yapıya sahiptir. Kireç taşları çok ince taneli karbonat ya da karbonat çamurlarından meydana gelmektedir (Öztank ve Türkmen, 2001). 


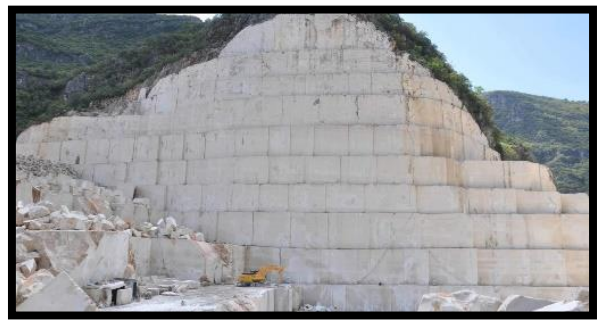

Şekil 3.10'da Kireç Taşı (Limra) açık ocak işletmesi görülmektedir. Ocaktan çıkarılan bu taş kolay işlenebilir olduğu için duvar kaplamalarında, küpeşte, denizlik ve heykel yapımında tercih edilmektedir.

Şekil 3.10. Kireç Taşı (Limra) Açık Ocak İşletmesi, Antalya (Yüksel, 2010)

\section{Toprakkale Bazaltı}

Genellikle siyah renkli olan, ağır ve sağlam bir taş olmasıyla bilinen Bazalt taşı, Osmaniye iline bağı Toprakkale ilçesinde yoğun biçimde bulunmaktadır. Ocaktan kolayca çıkarılan bir doğal taş olarak Toprakkale Bazaltı, buna karşın işlenmedeki güçlükler ve yüksek fiyat sebebiyle çok yaygın olarak değerlendirilmeyen bir taştır (Altınçekiç, 2001).

Toprakkale Bazaltının kullanım alanlarına göre uygunluğu aşağıdaki çizelge üzerinde gösterildiği gibidir.

\section{Köfke Taşı}

Köfke taşı, Isparta ilinin yerel taşlarından birisi olarak anılmaktadır ve köprü yapımı, parkların döşemesi gibi kullanım alanları mevcuttur. Isparta ilinde köfke taşı ile yapılmış 8 adet köprü bulunmaktadır ve köfke taşı sağlam bir taş olarak anılmaktadır (URL-21).

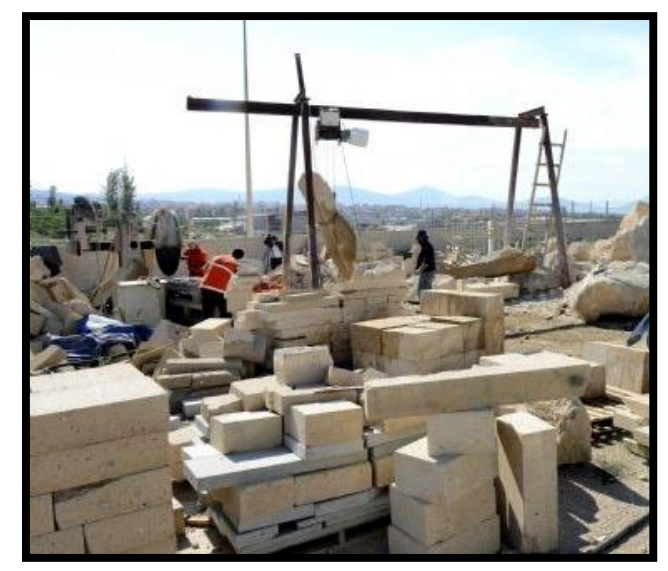

Isparta ili içerisinde çıkarılan köfke taşı jeolojik miras olarak birçok mimari yapıda kullanılmış olup Şekil 3.11.'de görüldüğü üzere günümüzde de işlenmeye devam edilmektedir.

Şekil 3.11. Isparta Köfke Taşı İşletme Atölyesi (URL-22)

Farklı isimlerle anılan köfke taşı yöresel olarak topuzlu taş, kale taşı, sille taşı gibi isimlerle anılmaktadır (Taşlıgil ve Şahin, 2016). "Magmatik taşlardan olup silis oranı \% 62 - 64 ve genellikle gri renkli bir kayaçtır. Diğer magmatik taşlar gibi muhtelif doğrultularda çatlaklar ihtiva ettiklerinden ocaklardan da belli büyüklükte bloklar halinde çıkartılarak kullanılırlar" (Taşlıgil ve Şahin, 2016).

"Isparta kentinde, özellikle anıtsal mimaride, eskiden beri en çok kullanılan yapı malzemesi, yöredeki ocaklardan elde edilen ve yöre halkı tarafından "köfke" olarak isimlendirilen kaynaklanmış tüfler ile yine Gölcük volkanizmasının ürünü olan traki-andezitlerdir" (Sargın, 2005).

\section{Tüf}

Doğal taşların kullanım alanına göre incelenmesi ile birlikte parlatılarak kullanılan doğal taşlar ve parlatılmadan kullanılan doğal taşlar şeklinde bir sınıflandırma ortaya çıkmaktadır. Tüf taşı, parlatılmadan kullanılan doğal taşlar arasında yer almaktadır (Güneri, 2009).

Tüf taşının doğaya uyumlu bir taş olmasının yanında aşınmayan bir yapıda olduğu, sulama ihtiyacını azalttığı, yangına karşı dayanıklı olduğu, yerleştirilmesinin kolay olduğu, ağaç ve çalıları çevrelemede kullanıldığı, renklerinin solmaya karşı dayanıklı bir yapıda olduğu, topraktaki nemi korumada yardımcı roller üstlendiği bilinmektedir. 


\section{Geyran Taşı (Andezit)}

Geyran Taşı, Isparta bölgesinin traki andezitlerinden birisi olarak görünmektedir (Özkahraman ve Işık, 2003). Bu taşın Isparta bölgesinde çıkarılarak Türkiye'nin ve dünyanın farklı yerlerinde - bina yapımı gibi amaçlarla - kullanılması söz konusudur.

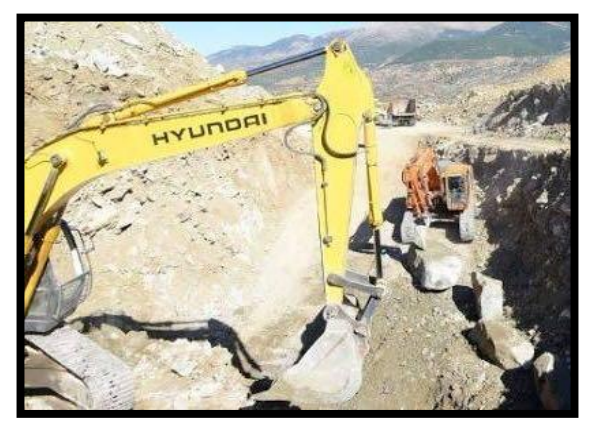

Yöresel ismi Geyran taşı olan Isparta Belediyesi tarafından işletilip dünyaya Andezit olarak tanıtılan jeolojik miras niteliğindeki bu taş Şekil 3.12'de görülen ocaklarda çıkartılmaktadır.

\section{Sonuç ve Öneriler}

Doğal taşlar, tüm yörelerde bulunabilmelerinin bir sonucu olarak, ilk çağlardan günümüze değin geçen süreç içerisinde çeşitli amaçlar için, en yaygın biçimde kullanılan materyallerden olmuştur. Peyzaj mimarlı̆̆ında da doğal taşlardan gerek yapı gerekse kaplama malzemesi olarak (döşeme, duvar, bordür vb.) yararlanılmaktadır. Doğal taşın bu alandaki kullanımı da peyzaj sanatı tarihi kadar eskidir. Peyzaj mimarlığı çalışmalarında doğal taşların tercih edilmesinde işlevsel, estetik ve dayanıklı olmaları etken olmaktadır. Gerçekten de doğal taşlar kullanışlı ve sağlam olmanın yanı sıra renk ve tekstür açısından da çeşitlilik sunmaktadır. Gelişmiş ülkelerde, yapay malzemeleri oldukça az kullanmak, insanları doğayla yakınlaştırmak için doğal malzemeler kullanılması gibi eğilimler ön planda olduğundan peyzaj düzenlemelerinde doğal taş kullanımı oldukça yaygın olarak görülmektedir (Altınçekiç, 2001).

Türkiye'de doğal taş varlığı açısından yapılan incelemeler rezerv ve çeşitlilik yönünden büyük bir potansiyelin varlığını göstermektedir. Türkiye, coğrafi konumunun avantajıyla doğal taş bakımından önemli bir konumdadır. Yine Türkiye'de doğal taş kullanımıyla yapılmış pek çok tarihi yapı bulunmaktadır. Tüm bu sonuçlar Türkiye'de doğal taşların jeolojik bir miras olarak değerlendirilmesi gerekliliğini beraberinde getirmektedir.

Mimarlık ve sanat tarihi, aynı zamanda doğal taşların kullanım tarihidir (Farrelly, 2011). Bütün ünlü yapıların taşlarının nerelerden getirildiği belgelidir. Yapılara yenileme veya bakım gerektiğinde orijinal taş ocaklarının kullanılması önerilmektedir. Çünkü zaman içinde yapı ünlenirken, onu görkemli kılan taşlar daha çok aranır olmakta, böylece eserler gibi orada kullanılan taşlar da "ulusal değer" halini almaktadır. Bu bir süreçtir ve yaşanmış olması şanstır. Bütün gelişmiş ülkeler böyle doğal taşları ve taş ocaklarını "doğal ve kültürel sit", genellikle de "jeolojik miras" olarak görmektedirler (örn. BGS, 2011; EGS, 2011; USGS, 2012). Bu çalışmanın bir diğer amacı yukarıda adı geçen, ülkemize ait taşların jeolojik miras olarak algılanmasına yardımcı olmaktır. Toplum sahip olduğu değerlerin farkına vardıkça, onları koruma ve geliştirmede daha duyarlı olacaktır (Kazancı ve Gürbüz, 2014).

Malzemeler mimarlıkta bir atmosfer yaratır, yapının dokusunu ve maddi özünü oluştururlar. Malzemelerin etkin olarak nasıl kullanılacağını bilmek için tasarımcının önceden yapılmış olan binalara veya malzemelerin tarihsel süreç boyunca nasıl kullanıldığına ilişkin bilgiye sahip olması, malzeme uygulamalarındaki gelişmelerin farkında olması gerekir. Bunlar birçok tasarımın geliştirilmesinde yararlı bir yöntem sunabilir (Farrelly, 2011)

Doğal taşlar tarih boyunca değişik medeniyetler tarafından özellikle anıtlarda ve görkemli yapılarda kullanılmıştır. Günümüzde zemin döşemelerinde (\%40), iç ve dış kaplamada (\%27), anıt yapılarda ve mezarcılıkta (\%13), süs eşyası yapımında (\%8) ve diğer alanlarda (\%12) kullanılmaktadır (URL, 23).

Ülkemizde kişilikli kentlerin ortaya çıkmasına yol açabilecek böyle uygulamalar, başka ülkelerde çoktan başlamış ve artan şekilde teşvik edilmektedir (Heldal ve Neeb, 2000; BGS, 2011; USGS, 2012). 
Şehirlerin tescilli taşlardan oluşturulmasına katkıda bulunmak üzere, Jeolojik Mirası Koruma Derneği bu doğal taşları kendi listesinde jeomiras olarak kayda geçirmiştir. Yerel yönetimlerin de Türk Patent Enstitüsü'nde aynı taşlar için "coğrafi marka" tescili yaptırmaları için çabalarını sürdürmektedir (Kazancı ve Gürbüz, 2014).

\subsection{Jeolojik Miras Niteliğindeki Doğal Taşların Kullanım Alanları}

\section{- Zemin Döşemesi}

Zemin döşemelerinde jeomiras niteliği taşıyan doğal taşların geniş bir kullanım alanının olduğu bilinmektedir. Peyzaj tasarımlarında sıklıkla kullanılan yürüyüş yolları, havuz kenarları, meydanlar gibi sert zemin döşemelerinde genellikle traverten, mermer, bazalt ve Geyran taşı öne çıkan doğal taşlar olarak görünmektedir. Kullanım pratikliği, dayanıkııık ve estetik açısından bu doğal taşların zemin döşemesinde daha çok tercih edildiği yönünde bir çıkarım yapılabilir.

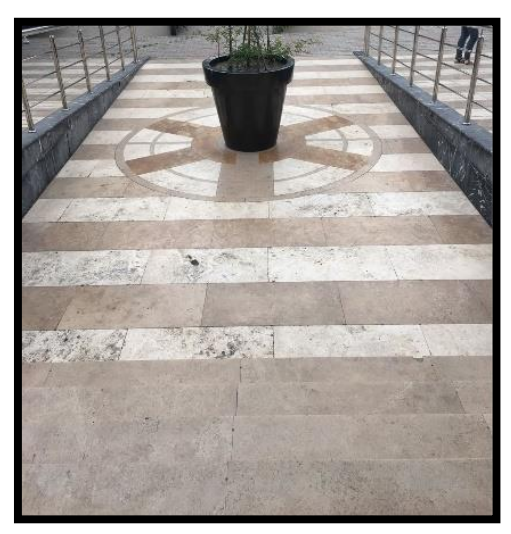

Şekil 4.1'de traverten taşının değişik renklerinin bir arada kullanıldığı geometrik desenli bir sert zemin uygulaması görülmektedir.

Şekil 4.1. Traverten ve Siyah Mermer Zemin Döşemesi, Isparta (Yüksel, 2018)

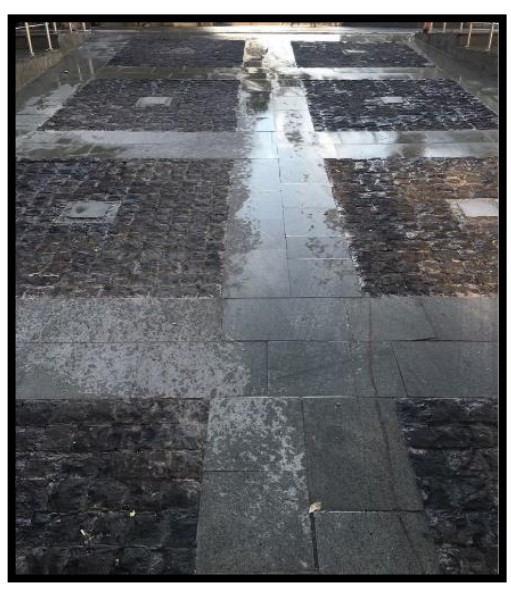

Şekil 4.2'de kırma yüzeyli bazalt küp taş ve Geyran taşının birlikte kullanıldığı bir uygulama görülmektedir.

Şekil 4.2. Geyran Taşı (Andezit) ve Kırma Bazalt Zemin Döşemesi, Isparta (Yüksel, 2018)

\section{- Duvar Kaplaması, Köprü ve Sütunlar}

Jeolojik miras niteliği taşıyan doğal taşların peyzaj tasarımında kullanımında duvar kaplaması için kuru taş duvar, harçlı taş duvar, kesme blok taş duvar gibi farklı seçenekler bulunmaktadır. Duvar kaplaması, köprü ve sütunlar için kullanılacak olan taşların dayanıkılığı yüksek, harca yapışma ve pürüzlülük açısından yeterli, homojen ve damarsız olmasına özen gösterilmesi gerekmektedir. Peyzaj tasarımlarında yapı elemanı olan duvar, köprü ve sütunlarda genellikle jeolojik miras niteliği taşıyan Geyran taşı (Andezit), köfke taşı ve kireç taşının kullanıldığı görülmüştür. 


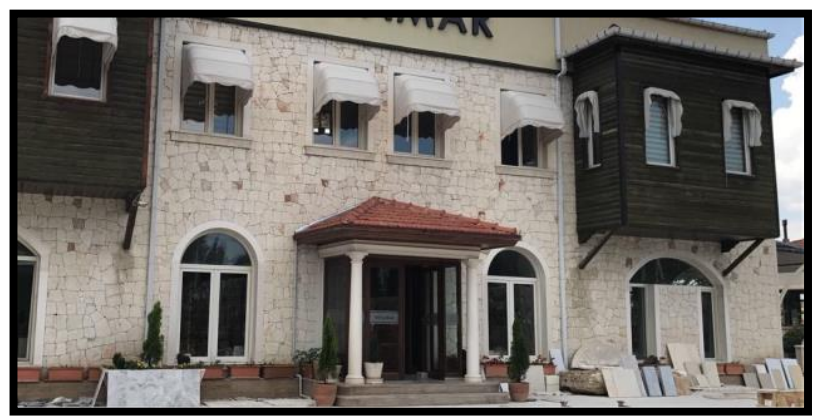

Şekil 4.3'te kolay işlenebilir bir taş olan kireç taşı ile yapılmış kırma taş duvarlar, sütunlar ve söveler görülmektedir.

Şekil 4.3. Kireç Taşı (Limra) Kırma Duvar Kaplaması ve Sütun Uygulaması, Isparta (Yüksel, 2018)

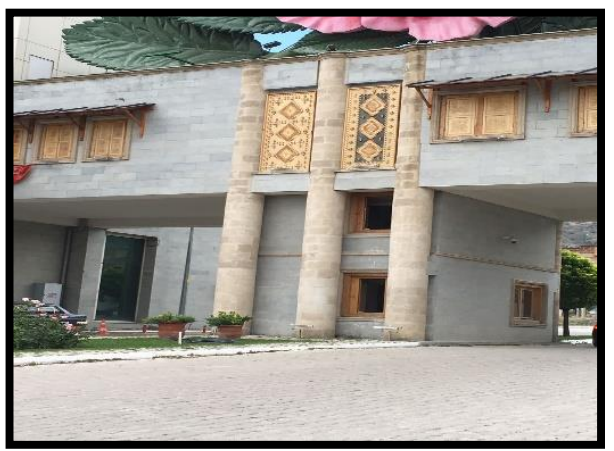

Şekil 4.4. Geyran Taşı (Andezit) Duvar Kaplaması ve Köfke Taşı Sütun Uygulaması, Isparta (Yüksel, 2018)

Şekil 4.4'te bulunan giriş kapısının duvar kaplamalarında Geyran taşı (andezit) kullanılmış ve sütunları ise köfke taşından yapılmıştır.

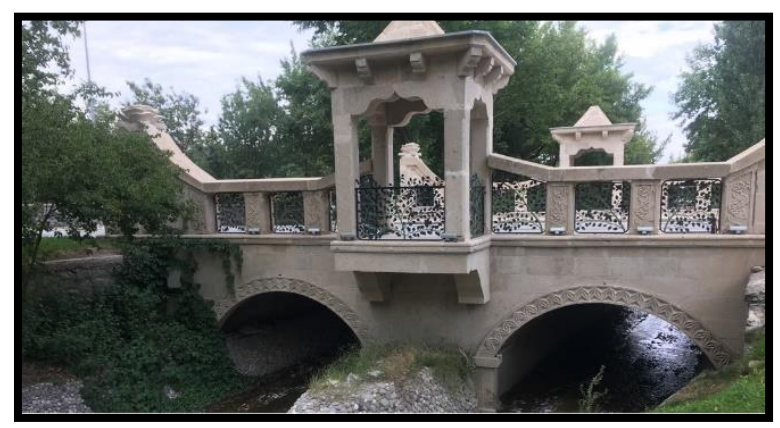

Şekil 4.5. Köfke Taşı Köprü Uygulaması, Isparta (Yüksel, 2018)

\section{- Donatı Elemanları}

Kentsel donatı elemanları, tanımlayıcı, belirleyici, yönlendirici ve bilgilendirici özelliklere sahip elemanlardır. Jeolojik miras niteliğindeki doğal taşlardan yapılan donatı elemanları için kentin kimliği ile özdeşleşebilecek bir kültürel boyuttan söz edilmektedir.

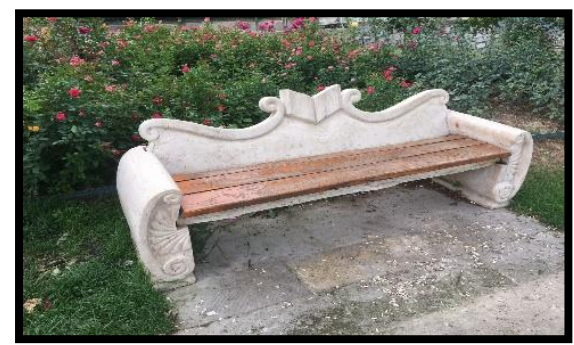

Jeolojik miras niteliğindeki doğal taşlardan yapılan heykel, bank ve çeşme vb. donatı elemanlarında mermer, traverten ve köfke taşı gibi doğal taşlar kullanılmaktadır. Şekil 4.6'da travertenin dekoratif bir şekilde ahşap ile birleştiği bir bank görülmektedir.

Şekil 4.6. Traverten Bank Uygulaması, Isparta (Yüksel, 2018) 


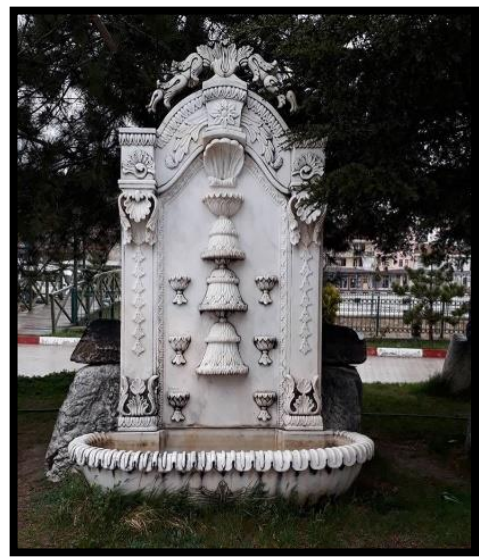

Şekil 4.7'de el işçiliği ile mermerden yapılmış bir çeşme görülmektedir.

Şekil 4.7. Mermer Çeşme Uygulaması, Afyon İscehisar (Yüksel, 2018)

\section{- Dekoratif Amaçlı Yüzeyler}

Dekoratif amaçlı yüzeyler ve jeolojik miras niteliği taşıyan doğal taş kullanımı konusunda estetik özelliğinin ön plana çıkmasına yönelik beklentiler de bulunmaktadır.

Jeolojik miras niteliğindeki doğal taşların işlendikten sonra kullanılabilir bir güzel sanatlar örneği olarak sanat ve teknik bilginin birlikteliği uyum içinde sergilenmelidir. Bireyler tarafından kolayca algılanmalarının sağlanması için görsel algılama ilkeleri doğrultusunda tasarlanmalıdırlar. İşlevsel, görsel oldukları kadar sanat eseri değerinde oldukları unutulmamalıdır. Kentsel mekânlarda, park, kent meydanı gibi yerlerde yer alan bu elemanların tasarımlarında, sanatsal yaklaşım göz önünde bulundurulursa, uygulandığı yerlere kimlik kazandıracak niteliğe sahip olacaktır.

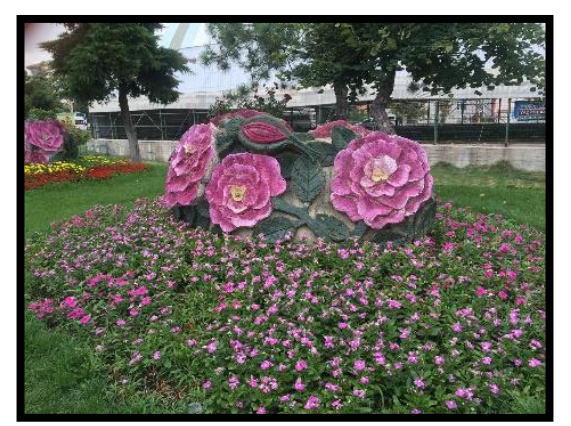

Şekil 4.8'de yörenin simgesi olan Isparta gülünün köfke taşına yapılan yüzey uygulaması görülmektedir.

Şekil 4.8. Köfke Taşı Dekoratif Yüzey Uygulaması, Isparta (Yüksel, 2018)

- Havuzlar

Süs havuzlarının sayesinde bahçelerimizde estetik görünümün yanında adeta bir huzur ortamı oluşmaktadır. Peyzaj tasarımlarının olmazsa olmazı olan süs havuzları farklı tasarımlarda ve şekillerde tasarlanmaktadır.

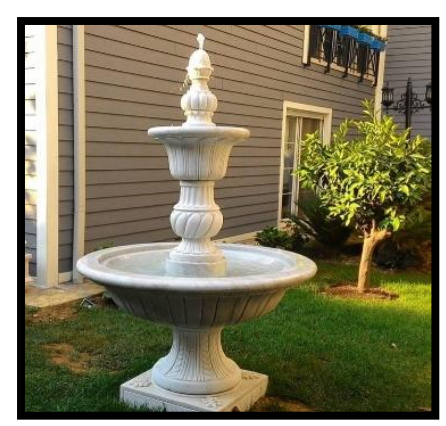

Şekil 4.9'da suyun yukarıdan kademeli aktığı mermerden yapılan bir süs havuzu görülmektedir.

Şekil 4.9. Mermer Süs Havuzu Uygulaması

Doğal taşların peyzaj düzenlemelerinde kullanımı, düzenlemelerin görsel kalitesini artırmakta, insan doğa yakınlaşmasında da önemli bir işlev görmektedir. Ancak söz konusu taşların kullanımında, kullanım yeri ve amacının doğru belirlenmesi zorunludur. Bu belirlemenin sağlıklı yapılabilmesi de 
materyalin fiziksel ve kimyasal özelliklerinin bilinmesi ile mümkün olabilecektir. Ayrıca düzenlemenin görsel kalitesinin artırılmasında, seçilen doğal taş kadar kullanılan diğer sert yapı malzemelerinin birbirleriyle görsel ilişkileri de büyük önem taşımaktadır. Son olarak vurgulanması gereken diğer bir konuda, peyzaj projelendirme ve uygulama çalışmaları yapacak kişilerin, yani peyzaj mimarlarının doğal taşların üretildikleri yerleri ve standart üretim boyutlarını bilmeleri gerekliliğidir (Altınçekiç, 2001).

Çalışmada ulaşılan sonuçlar göz önünde bulundurularak aşağıdaki öneriler getirilmektedir:

- Günümüzde maalesef yerel yönetimler kentsel alanlarda döşeme, donatı ve dekoratif amaçlı yüzeylerde ve özellikle sirkülasyonların yenilenmesinde özgün doğal taşları bozup yöreye ait olmayan hatta doğal olmayan taşları kullanmaktadırlar. Oysa belli bir yaşam kültürünü ve geçmişi simgeleyen jeolojik miras niteliğine sahip doğal taşları kullanmak mevcut alanlara ve yapılara daha da çok değer katacak ve kimlik kazandıracaktır. Bu nedenlerle jeolojik miras niteliğindeki doğal taşların kullanımına öncelik verilmelidir.

- Doğal taş uygulamalarında tasarımcı kullandığı taşın özellikleri hakkında bilgi sahibi olmalı ve nerede, hangi doğal taşın kullanılması gerektiği konusunda doğru kararlar vermelidir. Başarıı bir uygulamanın ilk şartı kullanılan malzemeyi her yönüyle iyi bir şekilde tanımaktır.

- Tasarımcıların, bina veya mekân yapımında kullanmadan önce malzemelerin doğasına, sunduğu olanaklara ve sınırlamalarına ilişkin fikre sahip olması gerekir.

- Ayrıca düzenlemenin görsel kalitesinin artırımasında, seçilen doğal taş kadar kullanılan diğer sert yapı malzemelerinin birbirleriyle görsel ilişkileri de büyük önem taşımaktadır. Son olarak vurgulanması gereken diğer bir konuda, peyzaj projelendirme ve uygulama çalışmaları yapacak kişilerin, yani peyzaj mimarlarının doğal taşların üretildikleri yerleri ve standart üretim boyutlarını bilmeleri gerekliliğidir (Altınçekiç, 2001)

- Jeolojik miras niteliği taşıyan doğal taşlar peyzaj alanında kullanılırken doğal taşların fiziksel ve mekanik nitelikleri dikkate alınarak uygun kullanım alanlarının belirlenmesi gerekmektedir.

- Jeomiras nitelikli doğal taşların tarihsel dönemlerde işletildikleri ocakların da başlı başına kültürel jeoloji açısından zenginlik olduğu ve mutlaka korunmaları için ele alınmaları gereklidir (Kazancı ve Gürbüz, 2014).

- İklim ve atmosferik özellikler göz önünde bulundurularak doğal taşların kullanım kararının verilmesi önerilmektedir (Yavuz, 2010)

- Jeolojik miras niteliği taşıyan doğal taşlar ve antik kentlere sahip çıkmanın temel görevler arasında olduğu bilincine sahip olunmalıdır.

- Peyzaj tasarımında doğal taş kullanımında sürekliliğin sağlanması ve hataların minimum seviyeye indirgenmesine katkı sağlayacak olan teknik detaylara özen gösterilmesi önerilir. Peyzaj tasarımında doğal taş kullanımına ilişkin fonksiyonelliğin dikkate alınması önerilmektedir.

- Türkiye'de jeolojik miras niteliği taşıyan doğal taşlar ve antik kentlerin yasalar aracılığıyla devlet tarafından koruma altına alınması önerilmektedir.

- Jeomiras nitelikli doğal taşların tarihsel dönemlerde işletildikleri ocakların da başlı başına kültürel jeoloji açısından zenginlik olduğu ve mutlaka korunmaları için ele alınmaları gerekmektedir (Kazancı ve Gürbüz, 2014).

- Doğal taş sektörünün devlet tarafından desteklenmesi ve teşvikler verilmesine yönelik düzenlemeler yapılmalıdır.

Bu nedenlerle yakın çevremizde bulunan jeolojik miras niteliğindeki doğal taşların kullanıma alınması ve peyzaj mimarlığı uygulama alanlarında yer verilmesi önemlidir. Bu çalışmada jeolojik miras niteliğindeki doğal taşların peyzaj tasarım alanındaki kullanım alanları belirtilirken, jeolojik miras 
anlamında da önemi gözetilerek vurgulanmak istenmiştir. Akdeniz bölgesinde jeolojik miras niteliğindeki doğal taşların neler olduğu ve peyzaj mimarlığı çalışmalarında kullanılabilecek bu doğal taşların özellikleri, türleri, ocak yerleri, kullanım yer ve amaçlarının ayrıntılı bir şekilde ortaya koyulması hedeflenmiştir.

\section{Kaynaklar}

Altınçekiç, H. (2001). Bazı doğal taşların irdelenmesi ve peyzaj düzenlemelerinde kullanım olanakları, ístanbul Üniversitesi Orman Fakültesi Dergisi, 51 (1), 49-57.

Altunel, E. (1996). Pamukkale travertenlerinin morfolojik özellikleri, yaşları ve neotektonik önemleri. Maden Tetkik ve Arama Dergisi, 118, 47-64.

Bağcı, M., Yıldız, A., Başaran, C. (2014). İscehisar mermer ocak ve fabrikalarda oluşan artıkların agrega olarak kullanılmasının araştırııması. Yapı Teknolojileri Elektronik Dergisi, 10 (1), 7-14.

Bingöl, Z. (2004). Akdeniz bölgesinin kültür ve inanç turizmi potansiyeli açısından değerlendirilmesi. Bilgi Dergisi, 8 (1), 125-137.

Çelik, M.Y. (2003). Dekoratif doğal yapı taşlarının kullanım alanları ve çeşitleri. Madencilik Dergisi, 42 (1), 3-15.

Değerli, B. (2015). Peyzaj tasarımında kullanılan doğal taşların fiziksel ve petrografik özelliklerinin, hiperspektral yansıma özellikleriyle karşılaştırılması. Ondokuz Mayıs Üniversitesi, Fen Bilimleri Enstitüsü, Harita Mühendisliği Anabilim Dalı, Yüksek Lisans Tezi, Samsun.

Farrelly, L. (2011). Mimarlığın Temelleri (Çev. Neslihan Şık). Literatür Yayınları, Akademik Temeller Dizisi 01, İstanbul.

Güneri, S. (2009). Doğal taşların teknik özelliklerine göre kullanım alanlarının ve uygulama parametrelerinin belirlenmesi. Dokuz Eylül Üniversitesi Fen Bilimleri Enstitüsü Yüksek Lisans Tezi, 175s, İzmir.

Karaca, Ö. (2006). Anadolu antik kentleri. Uluslararası Amisos Dergisi, 2 (2), 88-108.

Kazancı, N., Gürbüz, A. (2014). Jeolojik miras nitelikli Türkiye doğal taşları. Türkiye Jeoloji Bülteni, 57 (1), 19-44.

Kazancı, N., Şaroğlu, F., Suludere, Y. (2015). Jeolojik miras ve Türkiye jeositleri çatı listesi. Maden Tetkik ve Arama Dergisi, 151, 263-272.

Kılıç, Ö., Anıl, M. (2006). Kireç söndürme şartlarının söndürülmüş kireç kalitesine etkisi. Madencilik Dergisi, 45 (1), 15-22.

Kılınçarslan, Ş., Başyiğit, C., Aktaş, H., Çankıran, O., Ürgüp, M.N., Uzun, İ. (2007). Yalvaç Pisidia Antiocheia kentinde kullanılan tuğla ve bağlayıcı malzemelerin kimyasal, fiziksel ve mekanik özelliklerinin araştırılması. Yapı Teknolojileri Elektronik Dergisi, 2, 1-6.

Kıraç, S., Kıraç, I. (2011). Aspendos yüzey araştırması. Anadolu Akdeniz Arkeoloji Haberleri, 9, 142-148.

Kuter, N., Erdoğan, E. (2006). Yalvaç, Pisidia Antiocheia antik kenti ve çevresinin peyzaj özellikleri ve turizm açısından değerlendirilmesi. Süleyman Demirel Üniversitesi Orman Fakültesi Dergisi, 1, 111-123.

Özkahraman, H.T., Işık, E.C. (2003). Isparta kaynaklanmış tüflerinin kaplama taşı olarak kullanılmasının önemi ve uygun yapıştırma harcı üretimi. Türkiye IV. Mermer Sempozyumu Bildiriler Kitabı, 18-19 Aralık, 201-212.

Öztank, N., Türkmen, F. (2001). Mermer-kireçtaşı ve konglomeraların yapılarda kullanımını denetleyen parametreler. Türkiye III. Mermer Sempozyumu, 3-5 Mayıs, 123-132.

Polat, S. (2011). Türkiye'de traverten oluşumu, yayılış alanı ve korunması. Marmara Coğrafya Dergisi, 23, 389428.

Ramazanoğlu, G. (2009). Adana'da Roma dönemi köprüsü: Taşköprü. Çukurova Üniversitesi Sosyal Bilimler Enstitüsü Dergisi, 18 (1), 305-322.

Sargın, S. (2005). Isparta'da kentsel koruma. Doğu Coğrafya Dergisi, 14, 251-281.

Seçkin, Ö.B. (1997). Peyzaj Yapıları II. i.Ü. Orman Fakültesi Yayın No: 447, i.ü. Yayın No: 4029, i. Ü. Basımevi ve Film Merkezi, İstanbul.

Sel, E. (2006). Dünya ve Türkiye ölçeğinde doğal taş ve seramik kaplama malzemelerinin sektörel analizi. İstanbul Teknik Üniversitesi Fen Bilimleri Enstitüsü Yüksek Lisans Tezi, 91s, İstanbul. 
Taşlıgil, N., Şahin, G. (2016). Yapı malzemesi olarak kullanılan Türkiye doğal taşlarının iktisadi coğrafya odağında analizi. Marmara Coğrafya Dergisi, 33, 607-640.

Ulu, M.í. (2009).Türkiyede Doğal Taş Kullanım Kültürü ve Kireçtaşının Önemi, İstanbul.

Üstol, G., Balkaya, Ç., Kanyoncuoğlu, Ü.Y. (2013). Pisidia Antiokheia antik kentinde yer radarı ve elektrik özdirenç tomografi araştırmalarının ilk sonuçları. Türkiye 20. Uluslararası Jeofizik ve Kongre Sergisi, $25-$ 27 Kasım, 14-17.

Yavuz, H. (2010). Doğal taş elemanlarının peyzaj düzenlemelerinde kullanımı, İstanbul Teknik Üniversitesi Fen Bilimleri Enstitüsü Yüksek Lisans Tezi, 155s, İstanbul.

Yüksel, U. (2010). Kişisel Fotoğraf Arşivi.

Yüksel, U. (2018). Kişisel Fotoğraf Arşivi.

URL-1. Mülazımoğlu, N. ve Inaner, H. Türkiye'de Jeolojik Mirasın On Yılı,http://web.firat.edu.tr/jeokoruma/jeo/PDF/N.S.\%20M\%C3\%9CLAZIMO\%C4\%9ELU.pdf, Erişim Tarihi: 20.07.2018.

URL-2. http://www.dogaltas.net/taban-tugla-karisik-granit-kup-tas-.html, Erişim Tarihi: 20.07.2018.

URL-3. https://www.karotasyapi.com/bazalt/439276a0-915e-446c-a736-31547b780c02/, Erişim Tarihi: 20.07.2018.

URL-4. Web adresi: http://www.karotasyapi.com/kuptas-bazaltkuptas-travertenkuptas-andezit-kuptas/andezitparke/mutlu2-2/, Erişim Tarihi: 21.07.2018

URL-5. http://2egstones.blogspot.com/p/blog-page_9586.html, Erişim Tarihi: 21.07.2018.

URL-6. http://www.mermeryapimarket.com/havuz-taslari-traverten.html, Erişim Tarihi: 20.07.2018.

URL-7. http://www.marmaraflora.com/sert-zemin-uygulamalari/cim-derz-doseme-kayrak-4/, Erişim Tarihi: 19.07.2018.

URL-8. https://www.karotasyapi.com/dogal-taslar/limra/page/215/, Erişim Tarihi: 22.07.2018

URL-9. https://www.granices.com/bianco-carrara-mermer/, Erişim Tarihi: 19.07.2018.

URL-10. http://www.insaatderyasi.com/cakil-taslarindan-yapilan-muhtesem-dekorasyonlar-2316h.htm, Erişim Tarihi: 20.07.2018.

URL-11. http://www.tursaga.com/usrfiles/files/yayinlar/aglasun_ve_sagalassos_tr.pdf, Erişim Tarihi: 29.07.2018.

URL-12. http://gezginyuzlersitesi.com/gidilen/sagalassos-antik-kenti-burdur-emel-firatli/, Erişim Tarihi: 29.07.2018.

URL-13. http://www.hurriyet.com.tr/sagalassos-efsanesi-24500382, Erişim Tarihi: 02.08.2018.

URL-14. https://www.kulturportali.gov.tr/turkiye/adana/gezilecekyer/tas-kopru804491, Erişim Tarihi: 30.07.2018.

URL-15. https://perilce.com/mersinin-bilinmeyen-antik-kentleri/, Erişim Tarihi: 30.07.2018.

URL-16. https://yoldaolmak.com/olba-antik-kenti-silifke.html, Erişim Tarihi: 03.08.2018.

URL-17. http://www.hatayvakfi.org.tr/sayfa.php?SayfaTuru=gezi\&Sayfald=65217918, Erişim Tarihi. 31.07.2018.

URL-18. https://www.hataysa.com/listing/erzin-issos-antik-kenti/, Erişim Tarihi: 23.07.2018.

URL-19. https://www.kulturportali.gov.tr/turkiye/kahramanmaras/gezilecekyer/germanicia-antik-kenti, Erişim Tarihi: 31.07.2018.

URL-20. http://arkeolojihaber.net/tag/germenicia-antik-kenti/, Erişim Tarihi: 25.07.2018.

URL-21. http://www.isteisparta.com/newsdetails.asp?id=17469, Erişim Tarihi: 25.07.2018.

URL-22. http://www.isparta.bel.tr/haber.aspx?hid=3227, Erişim Tarihi: 23.07.2018.

URL-23. http://www.maden.org.tr, Dekoratif Doğal Yapı Taşlarının Kullanım Alanları ve Çeşitleri, (Ziyaret tarihi: 05.10.2017) 